\title{
EFEITO DO HORMÔNIO TIROIDEANO NA FUNÇÃO CARDÍACA NO MODELO DE ISQUEMIA/REPERFUSÃO EM RATOS. PAPEL DO RECEPTOR AT2 E DA VIA INTRACELULAR AMPK
}

Dissertação apresentada ao Programa de PósGraduação em Ciências Morfofuncionais do Departamento de Anatomia do Instituto de Ciências Biomédicas da Universidade de São Paulo, para obtenção do Título de Mestre em Ciências. 


\section{EFEITO DO HORMÔNIO TIROIDEANO NA FUNÇÃO CARDÍACA NO MODELO DE ISQUEMIA/REPERFUSÃO EM RATOS. PAPEL DO RECEPTOR AT2 E DA VIA INTRACELULAR AMPK}

Dissertação apresentada ao Programa de PósGraduação em Ciências Morfofuncionais do Departamento de Anatomia do Instituto de Ciências Biomédicas da Universidade de São Paulo, para obtenção do Título de Mestre em Ciências.

Área de concetração: Ciências Morfofuncionais.

Orientadora: Profa ${ }^{a}$. Dr ${ }^{a}$. Maria Luiza Morais Barreto de Chaves.

Versão original 
DADOS DE CATALOGAÇÃO NA PUBLICAÇÃO (CIP)

Serviço de Biblioteca e Informação Biomédica do

Instituto de Ciências Biomédicas da Universidade de São Paulo

reprodução não autorizada pelo autor

Tavares, Felix Meira.

Efeito do hormônio tiroideano na função cardíaca no modelo de isquemia/reperfusão em ratos. Papel do receptor $\mathrm{AT}_{2}$ e da via intracelular AMPK / Felix Meira Tavares. -- São Paulo, 2012.

Orientador: Maria Luiza Morais Barreto de Chaves.

Dissertação (Mestrado) - Universidade de São Paulo. Instituto de Ciências Biomédicas. Departamento de Anatomia. Área de concentração: Ciências Morfofuncionais. Linha de pesquisa: Ação hormonal na fisiopatologia cardiovascular

Versão do título para o inglês: Effect of thyroid hormone on cardiac function in the ischemia/reperfusion injury of wistar rats. Role of $\mathrm{AT}_{2}$ Receptor and AMPK signaling pathway.

Descritores: 1. Isquemia miocárdica 2. Hormônios tiroideanos 3. Angiotensina II 4. Hipertireoidismo 5.Sistema cardiovascular I. Chaves, Maria Luiza Morais Barreto de II. Universidade de São Paulo. Instituto de Ciências Biomédicas. Programa de Pós-Graduação em Ciências Morfofuncionais III. Título. 
Candidato(a):

Título da Dissertação:

Orientador(a):
Felix Meira Tavares.

Efeito do hormônio tiroideano na função cardíaca no modelo de isquemia/reperfusão em ratos. Papel do receptor $A T_{2}$ e da via intracelular AMPK.

A Comissão Julgadora dos trabalhos de Defesa da Dissertação de Mestrado, em sessão pública realizada a

Maria Luiza Morais Barreto de Chaves.
( ) Aprovado(a)
( ) Reprovado(a)

Examinador(a): Assinatura:

Nome:

Instituição:

Examinador(a): Assinatura:

Nome:

Instituição:

Presidente: Assinatura:

Nome:

Instituição: 


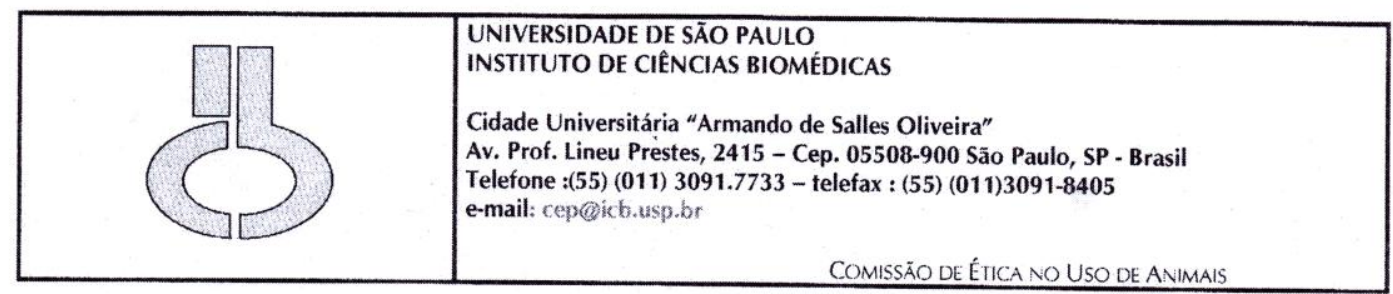

Decl. CEUA.003/2010

DECLARAÇ Ã O

Em adendo ao Certificado 114/04/CEEA, datado de 16.12.04 e por solicitação da Profa. Dra. Maria Luiza Morais Barreto de Chaves, responsável pela linha de Pesquisa, autorizo a inclusão do aluno Felix Meira Tavares ao Projeto de Pesquisa "Papel do sistema renina-angiotensina na hipertrofia cardíaca e/ou renal induzida pelos hormônios tiroideanos", uma vez que se trata de utilização da mesma espécie animal e de métodos experimentais similares ao referido certificado.

São Paulo, 09 de fevereiro de 2010.

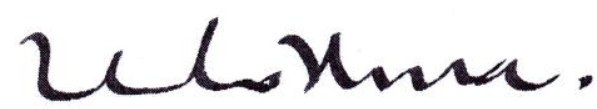

Prof. Dr. Wothan Tavares de Lima

Coordenador da CEUA ICB/USP 


\begin{abstract}
Aos Ratos de laboratório cuja lembrança haverá de ser eterna como a minha gratidão, grande como o altruísmo, eloquente como o seu gesto, dando tudo à mesma humanidade que tudo the negou em vida.
\end{abstract}




\section{AGRADECIMENTOS}

À minha orientadora $\operatorname{Prof}^{\mathrm{a}}{ }^{\mathrm{Dr}}{ }^{\mathrm{a}}$ Maria Luiza eu agradeço de coração pela oportunidade, confiança, compreensão e paciência. Levarei seus valiosos ensinamentos para minha vida pessoal e profissional.

À equipe do Laboratório de Biologia Celular e Anatomia Funcional (LBCAF), as palavras são insuficientes para expressar a beleza e o tamanho da minha gratidão a cada um de vocês. À Dayane Gomes que com muita paciência me ensinou a caminhar no meio científico; à Gabriela Diniz meu exemplo de competência e dedicação; à Caroline Emy a pessoa mais doce que conheci, levando harmonia por onde passa; À Caroline Lino com sua pureza e responsabilidade; à Priscilla Souza e sua generosidade infinita; à Ana Paula Takano sempre calma, voluntariosa e cheia de determinação; à Cristina Basso onde encontrei uma fonte inesgotável de amor e alegria e que me preenche de boas energias com a sua luz; à Marina Fevereiro eterna companheira e confidente que tranborda pestatividade e carinho; à Ivson Silva, irmão que possuo incomensurável sentimento de amizade, levando consigo uma energia de bondade, união e solidariedade; à Vanessa Lima e suas nobres atitudes de gentileza; à Ana Cláudia Barbosa sempre boa vontade para ajudar; à Mary Oliveira essa grande mãe sempre protegendo com sua benevolência; à Maria Brito que segue determinada a vencer com muita fé e sensibilidade; Ao Prof. Renato Chopard com sua serenidade e inteligência. A todos desse grupo, que nunca economizaram seus ouvidos para mim e sempre estavam prontos para me ensinar, aconselhar e ajudar sintamse autores dessa dissertação, pois a colaboração de cada um de vocês foi fundamental para que ela pudesse ser concluída com êxito.

Aos Professores Marcela Sorelli e Marcelo Chistoffolete pelo apoio e prontidão em me ouvir, obrigado pelos conselhos.

Ao Professor Dr. Dalton Vassalo agradeço imensamente pelos ensinamentos e pela boa vontade em ajudar, você foi de fundamental importância na contrução deste trabalho. 
Aos Professores Claudimara Lotfi, Vagner Antunes e Lisete Michelini, pela participação no meu exame de qualificação e pelas valiosas sugestões.

Ao professor Edson Liberti por me mostrar os passos desse processo sem retirar o foco no meu crescimento pessoal, gratidão pelo exemplo.

À secretaria de pós-graduação Patrícia, meus sinceros agradecimentos pela atenção e disponibilidade em todos os momentos

Às instutuições de fomento, CAPES, CNPq, e especialemnte à FAPESP, que concederam auxílio financeiro para a realização deste trabalho e de outros projetos desenvolvidos em nosso laboratório.

Aos amigos da pós-graduação do departamento de Anatomia da USP, em especial Carlos Haemmerle, Cleyton Sobrinho, Marília Bianca, Milena Freitas, Miguel Xavier e Priscila Rocha. Gratidão a cada um de vocês pelo convívio, pelos momentos maravilhosos que compartilhamos e pelo amor, que tenho a cada um em reciprocidade, o qual me fez ter inspiração para realização deste trabalho.

À Raphael Queiroz grande amigo que acreditou em meu potencial e sempre esteve de coração aberto para me ajudar, obrigado por tudo.

À Marcelo Boareto, companheiro de república, com quem dividi parte da minha história, levarei eternamente nossa cumplicidade

À Cleandho Sousa, primo que tive a honra de conhecer melhor, gratidão pelos ensinamentos sobre a vida, pelo carinho,afeto e atenção

À Adriana Peixoto amiga que me ajudou a enfrentar as disficuldades de morar distante da família, e se tornou a minha família aqui em São Paulo. Gratidão pelo amparo, pela confinaça e pelo amor

À meu cunhado José Eustáquio Junior que tornou possível a realização desse sonho, com seu apoio incondicional, amor sem medida e confiança, gratidão por tudo que tem me proporcionado nesta vida.

Ao meu sobrinho Artur Porto, que me envolve com sua energia pura, inocente e crística; gratidão por me proporcionar tanta alegria e despertar a cada instante o sentimento de amor incondicional.

Não menos importante, mas sim merecendo o maior destaque entre todos os agradecimentos, quero registrar aqui a minha eterna gratidão a minha 
irmã Joyce Porto, e a meus pais Djanildo Tavares e Ailta Meira que muitas vezes sacrifiram seus sonhos para que eu realizasse os meus, vocês são meus exemplos de determinação, perseverança, trabalho e honestidade. Gratidão pelo investimento e apoio incondicional à minha formação acadêmica e por suas sábias lições de esperança que me infundiram a confiança necessária para transpor obstáculos e prosseguir sempre.

A todos aqueles cujos nomes não foram citados, mas que direta ou indiretamente colaboraram para realização deste trabalho.

Após ter convivido com tantas dúvidas, inovações e expectativas do que eu seria ao fim desta jornada, consigo perceber mais claramente os desígnios divinos. E a esta etapa vencida, agradeço ao nosso criador, arquiteto do universo, por ter me dado subsídios mais que suficientes para este fim.

Hoje olho para o chão sob os meus pés e vejo a vida correr, e é diante da certeza de estar sempre começando, que ressalto a importância de todos vocês neste longo caminho ainda a ser trilhado. Escutarei o tempo, que me ensinará a decisão adequada em cada instante, e partirei em busca de muitos ideais. 
"O corpo humano é talvez uma simples aparência, escondendo a nossa realidade, e condensando-se sobre a nossa luz ou sobre a nossa sombra. A realidade é a alma. A bem dizer, o rosto é uma máscara. $O$ verdadeiro homem é o que está debaixo do homem. Mais de uma surpresa haveria se pudesse vê-lo agachado e escondido debaixo da ilusão que se chama carne. $O$ erro comum é ver no ente exterior um ente real. Tal criaturinha, por exemplo, se pudéssemos vê-la como realmente é, em vez de moça, mostrar-se-ia pássaro."

Victor Hugo

Os Trabalhadores do Mar 


\section{RESUMO}

Tavares, FM. Efeito do Hormônio Tiroideano na função cardíaca no modelo de Isquemia/Reperfusão em ratos. Papel do receptor AT2 e da via intracelular AMPK. Dissertação (Mestrado em Ciências Morfofuncionais) - Instituto de Ciências Biomédicas, Universidade de São Paulo, São Paulo, 2012.

O coração está sob ação direta de vários fatores endócrinos, como o Sistema Renina Angiotensina (SRA) e os Hormônios Tiroideanos (HT), capazes de modular direta ou indiretamente o trofismo e a proteção ao estresse cardíaco. Além de exercerem papel regulador em situações de injúria cardíaca, esses sistemas endócrinos interagem em muitas de suas ações. Os HT correspondem a um fenótipo de cardioproteção e influenciam no estado trófico do tecido cardíaco através de diversos mecanismos, dentre eles a modulação dos componentes do SRA - a Angiotensina II (Ang II), um potente peptídeo vasoativo, e seus receptores (AT1 e AT2). Estudos têm demonstrado que alterações na expressão do receptor AT2 no miocárdio estão intimamente relacionadas à resposta funcional do coração após injúria de Isquemia/Reperfusão (I/R), e que em situações de hipertiroidismo sua expressão está aumentada em $50 \%$. Dessa forma, os objetivos do presente estudo foram avaliar o papel do receptor AT2 na cardioproteção mediada pelo HT e a participação da proteína quinase ativada por AMP (AMPK), enzima relacionada com metabolismo e cardioproteção, nesse processo. Para responder a tais objetivos, o modelo de $\mathrm{I} / \mathrm{R}$ em corações isolados de ratos Wistar submetidos ao tratamento com T3 $(7 \mu \mathrm{g} / 100 \mathrm{~g}$ p.c por 14 dias), na presença ou na ausência do antagonista do receptor AT2 (PD123319) foi desenvolvido com a utilização do aparto de Langendorff. Os resultados obtidos mostraram que o HT exerce efeito cardioprotetor, acompanhado de um aumento na expressão protéica do receptor AT2 e da AMPK fosforilada. Este aumento foi prevenido com a administração do PD, que foi acompanhado com piora da função cardíaca. Em cojunto, estes dados sugerem que parte da cardioproteção induzida pelo HT é mediada pelo receptor AT2, e conta com a participação da AMPK na proteção do miocárdio após I/R.

Palavras-chave: Modelo de I/R. Hipertireoidismo. Receptores AT2. Cardioproteção. 


\section{ABSTRACT}

Tavares, FM. Effect of Thyroid Hormone on cardiac function in the Ischemia/Reperfusion injury of Wistar rats. Role of AT2 receptor and AMPK signaling pathway. Master thesis (Morphological Sciences) - Instituto de Ciências Biomédicas, Universidade de São Paulo, São Paulo, 2012.

Several endocrine systems, such as the renin-angiotensin system (RAS) and thyroid hormones (TH), may direct influence the cardiac function, directly or indirectly modulating the heart trophism and protectingagainst cardiac stress. Besides their regulatory role under situations of cardiac damage, the endocrine systems are able to interact in many of their actions. The TH correspond to a phenotype of cardioprotection and influence the trophic state of cardiac tissue through numerous mechanisms, including the modulation of RAS components the angiotensin II (Ang II), a potent vasoactive peptide and its receptors (AT1 and AT2). Previous studies have shown that changes in AT2 receptor expression in the myocardium are closely related to the functional response of the heart following ischemia/reperfusion $(\mathrm{I} / \mathrm{R})$ injury, and that its expression is increased by $50 \%$ in hyperthyroidism condition. This study aimed to evaluate the role of AT2 receptor in cardioprotection mediated by the TH and the involvement of AMP-activated protein kinase (AMPK), enzyme related to metabolism and cardioprotection, in this context. A model of $\mathrm{I} / \mathrm{R}$ was developed in isolated hearts of Wistar rats submitted to T3 treatment $(7 \mu \mathrm{g} / 100 \mathrm{~g} \mathrm{b.w}$. for 14 days) in the presence or absence of the AT2 receptor antagonist (PD123319), using the Langendorff apparatus. The results showed that $\mathrm{TH}$ exerts a cardioprotective effect accompanied by increased levels of AT2 and phosphorylated AMP protein expression. This increase was prevented by the administration of PD, which was accompanied by a loss of cardiac function. These data suggest that part of the $\mathrm{TH}$-induced cardioprotection is mediated by the AT2 receptor with the involvement of AMPK in the protection of myocardium after $\mathrm{l} / \mathrm{R}$ injury.

Keywords: Ischemia Repersusion Injury. Hyperthyroidism. AT2 receptors. Cardioprotection. 


\section{LISTA DE FIGURAS}

Figura 1 - Sistema de Langendorff (Radnoti-Adinstruments). 33

Figura 2 - Protocolo experimental de Isquemia e Reperfusão utilizado no estudo. 34

Figura 3 - Representação gráfica e fotográfica do coração no aparato de Langendorff 36

Figura 4 - Análise da razão peso do coração pelo comprimento da tíbia ........ 40

Figura 5 - Registro gerado pelo software LabChart 7.0 ................................ 42

Figura 6 - Pressão Desenvolvida pelo Ventrículo Esquerdo (LVDP), ,............. 43

Figura 7 - Primeira derivada positiva (+dP/dt) ………............................. 45

Figura 8 - Primeira derivada negativa (-dP/dt) ……................................. 47

Figura 9 - Frequência Cardíaca (FC) .................................................... 49

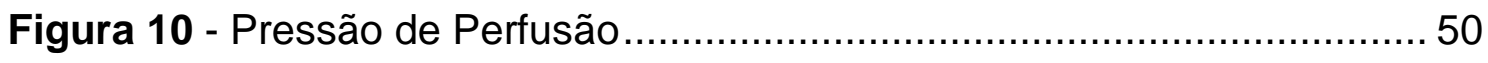

Figura 11 - Porcentagem de alteração dos parâmetros avaliados aos 25

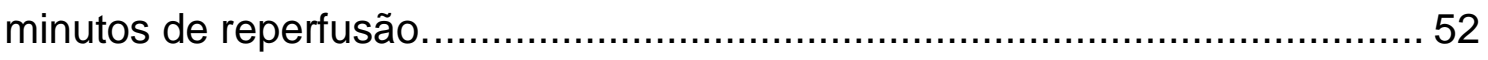

Figura 12 - Porcentagem de alteração dos parâmetros avaliado aos 35 minutos

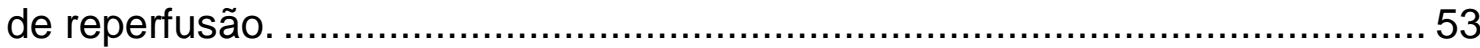

Figura 13 - Porcentagem de alteração dos parâmetros avaliados aos 45

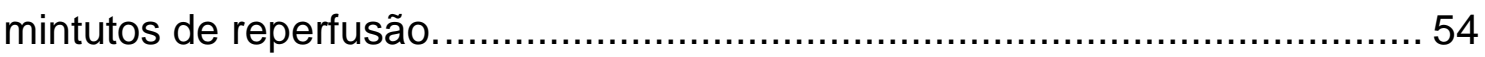

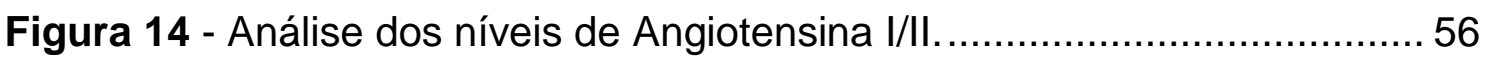

Figura 15 - Análise da expressão protéica do receptor AT1a e AT1b. ............ 56

Figura 16 - Análise da expressão protéica do receptor AT2 …....................... 57

Figura 17 - Análise da expressão protéica da AMPK .................................... 58 


\section{LISTA DE TABELAS}

Tabela 1 - Lista dos anticorpos primários utilizados para análise de expressão

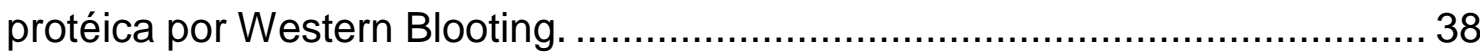

Tabela 2 - Dosagem sérica de Hormônios Tiroideanos .................................. 40

Tabela 3 - Avaliação do Peso úmido e Peso seco (em mg) do Pulmão e do

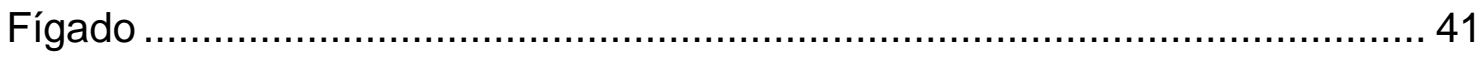




\section{LISTA DE ABREVIATURAS}

- dP/dt - primeira derivada negativa da pressão ventricular

+ dP/dt - primeira derivada positiva da pressão ventricular

Ang II - Angiotensina II

AMPK - quinase ativada por AMP

AT1 - receptor de Angiotensina II tipo 1

AT2 - receptor de Angiotensina II tipo 2

ECA - Enzima conversora de Angiotensina

ECG - Eletrocardiograma

eNOS - sintase de óxido nítrico do tipo endotelial

FC - Frequência Cardíaca

GAPDH - Gliceraldeído 3-fosfato desidrogenase

GLUT4 - Transportador de Glucose tipo 4

GSK3 $\beta$ - quinase glicogênio sintase $3 \beta$

HT- Hormônio Tiroideano

I/R - Isquemia e Reperfusão

KH - Krebs-Henseleit

LVDP - Pressão Desenvolvida pelo Ventrículo Esquerdo

LVEDP - Pressão Diastólica Final do Ventrículo Esquerdo

LVSP - Pressão Sistólica do Ventrículo Esquerdo

MAPK - proteína quinase ativada por mitógeno

PD ou PD123,319 - Antagonista seletivo do receptor AT2 de Angll

PKC - enzima fosfoquinase $C$

SRA- Sistema Renina Angiotensina

T3 - triiodotironina

T4 - Tiroxina 
1 INTRODUÇÃO

1.1 Hormônios Tireoideanos (HT) e Sistema Cardiovascular...................... 18

1.2 Sistema Renina-Angiotensina e Hormônios Tiroideanos (HT)............. 19

1.3 Isquemia/Reperfusão (I/R) e cardioproteção ......................................... 21

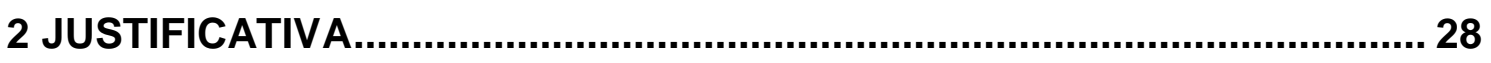

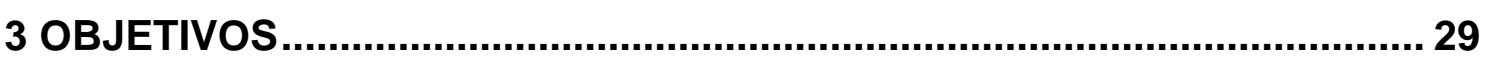

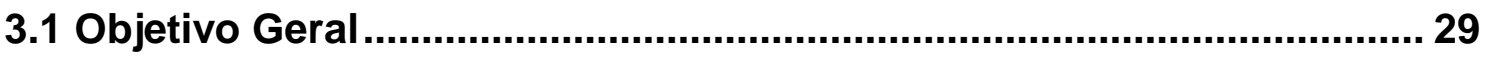

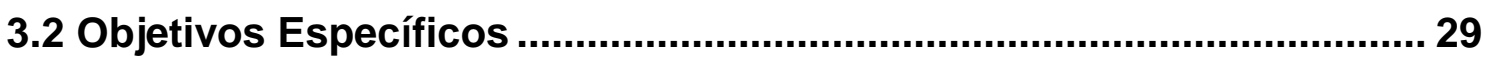

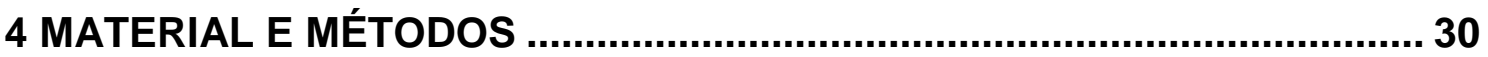

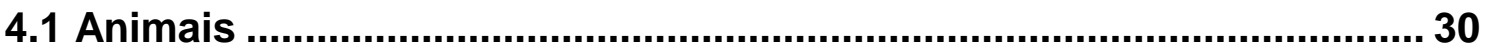

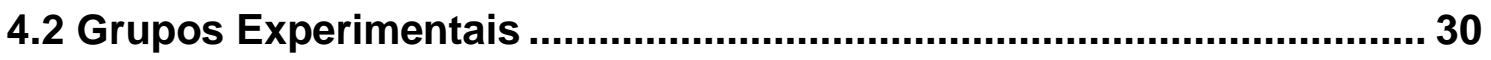

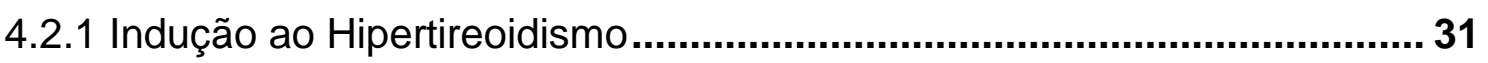

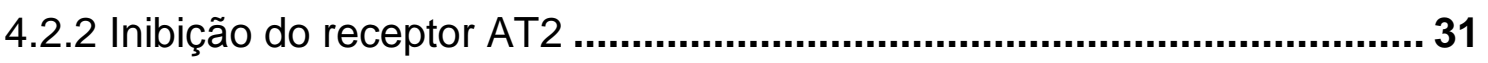

4.3 Dosagem Sérica dos Hormônios Tiroideanos ....................................... 31

4.4 Coleta de tecidos para cálculo da relação entre peso úmido e seco .. 32

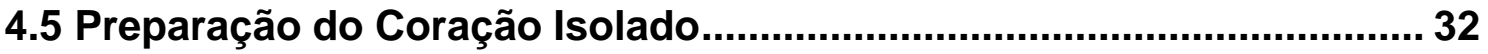

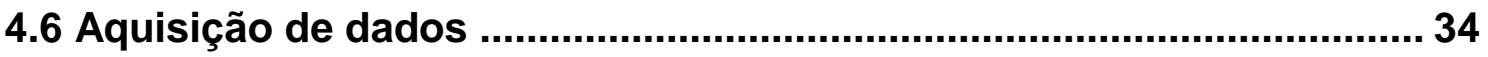

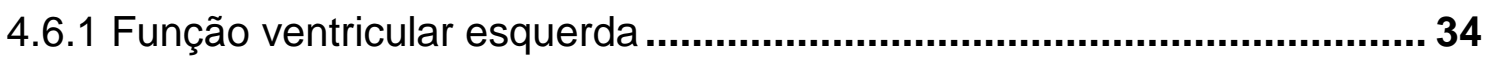

4.6.2 Eletrocardiograma e Frequência cardíaca............................................... 35

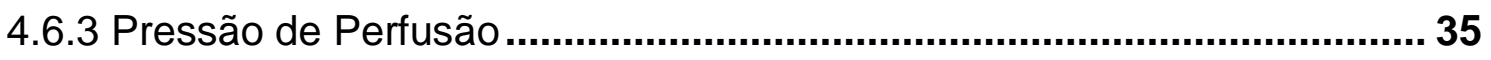

4.7 Análise dos níveis de Angiotensina I/II, da expressão dos receptores

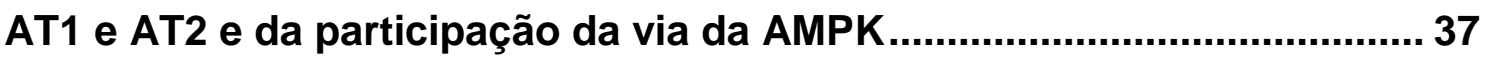

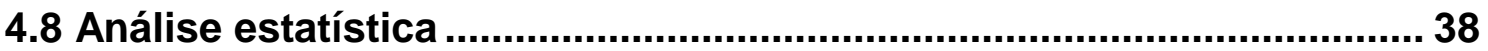

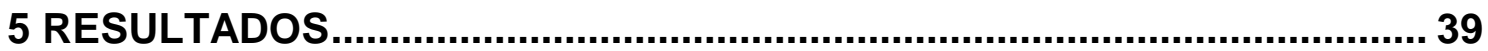

5.1 Efeito do bloqueio do Receptor AT2 na Hipertrofia Cardíaca induzida

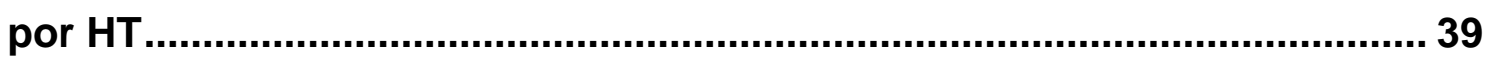

5.2 Efeito dos tratamentos sobre o teor de água pulmonar e hepático .... 41

5.3 Efeito do bloqueio do Receptor AT2 em parâmetros da função cardíaca, em animais hipertiroideos, frente a situações de I/R .................. 41

5.3.1 Pressão Desenvolvida pelo Ventrículo Esquerdo (LVDP) ....................... 42

5.3.2 Primeira Derivada Positiva das Pressões (+dP/dt) ................................. 43 


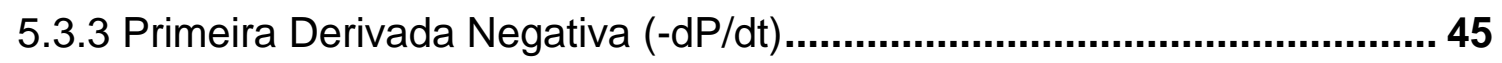

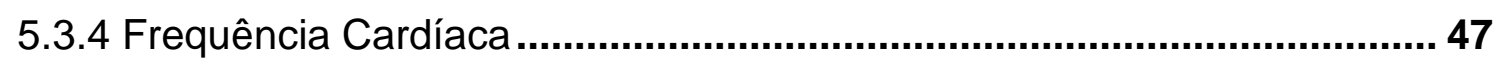

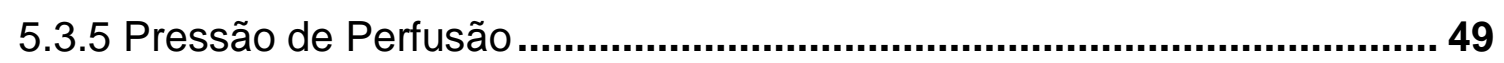

5.4 Efeito do bloqueio do Receptor AT2 na recuperação da função cardíaca, em animais hipertiroideos, frente a situações de $\mathrm{I} / \mathrm{R}$.................50

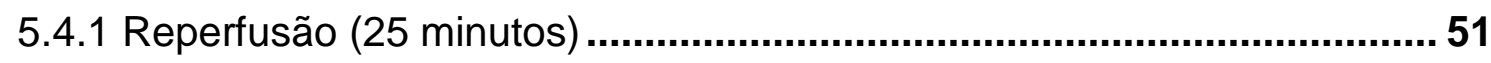

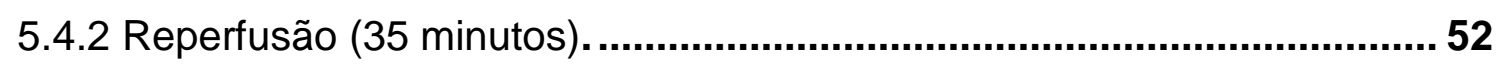

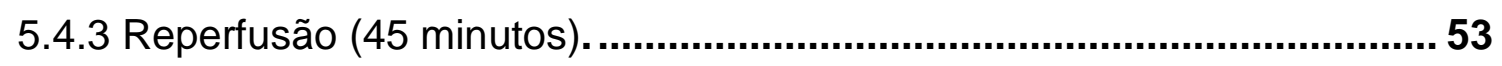

5.5 Análise dos níveis de Angiotensina I e II e da expressão dos receptores de Angiotensina II (AT1 e AT2) ........................................... 55

5.6 Efeito da Isquemia e Reperfusão no estado de fosforilação da AMPK nos diferentes grupos experimentais....................................................... 57

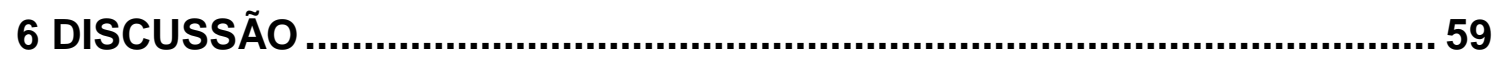

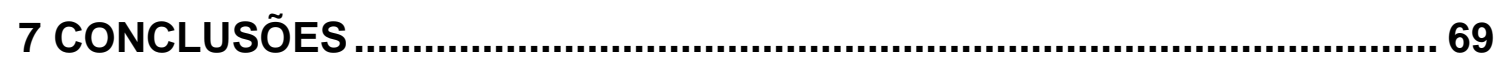

REFERÊNCIAS 


\section{INTRODUÇÃO}

\subsection{Hormônios Tireoideanos (HT) e Sistema Cardiovascular}

Os Hormônios Tiroideanos (HT) são produzidos pela glândula tiróide, sob estímulo de um hormônio adeno-hipofisário, o hormônio estimulante da tiróide (TSH), apresentam amplas funções sobre o metabolismo em geral, com importantes efeitos no sistema cardiovascular. Estes hormônios são divididos em dois tipos: o T4 ou tiroxina, que possui quatro iodos ligados ao seu anel benzênico, e o T3 ou triiodotironina, com apenas três iodos. Cerca de $90 \%$ do hormônio metabolicamente ativo que é secretado pela glândula corresponde ao T4, no entanto, o T3 apresenta uma potência biológica quatro vezes superior ao T4, mesmo que esteja presente no sangue em quantidades bastante inferiores. Após a liberação do T4 para a circulação, a maior parte do T4 é desiodada por ação da enzima 5'-desiodase, presente nos vários tecidos, se transformando em T3, que será finalmente utilizado. Este, após ligação aos respectivos receptores nucleares, exerce inúmeras funções intracelulares, tendo como destaque a regulação da transcrição de diferentes genes alvos (Yen, 2001).

No coração o T3 age aumentando a frequeência cardíaca (FC) e a fração de ejeção, contribuindo para o aumento do débito cardíaco. Embora o hormônio atue aumentando a pressão arterial sistólica, nem sempre este aumento ocorre concomitantemente ao aumento da pressão arterial média, uma vez que o mesmo promove diminuição da resistência vascular sistêmica. Como efeito final, o estado hipercinético do sistema cardiovascular, induzido por elevados níveis de HT, leva a um significativo aumento da massa muscular cardíaca, caracterizando uma situação de hipertrofia cardíaca (Danzi e Klein, 2004). Tendo como base esses vários efeitos cardiovasculares dos HT, entende-se porque a alteração da função cardíaca observada nas doenças da tireóide corresponde atualmente a um dos aspectos mais importantes e de grande relevância clínica tanto no hipo como no hipertireoidismo (Canaris et al., 2000; Kahaly e Dillmann, 2005).

Nos últimos anos, os estudos de nosso grupo evidenciaram a importante participação do Sistema Renina-Angiotensina em algumas das ações dos HT 
no sistema cardiovascular, sugerindo que este (SRA) possa agir como um importante mediador de ações cardiovasculares dos HT (Barreto-Chaves et al., 2010).

\subsection{Sistema Renina-Angiotensina e Hormônios Tiroideanos (HT)}

O Sistema Renina-Angiotensina (SRA) corresponde a um complexo sistema hormonal relacionado, entre outras funções, à homeostase do tecido cardíaco. Por quase um século o SRA foi classificado como um sistema endócrino, cujo hormônio efetor, a angiotensina II (Ang II), era o principal responsável pelos efeitos fisiológicos. No entanto, hoje se sabe que esse sistema é muito mais amplo e complexo do que o inicialmente suposto, com a ação de inúmeras outras enzimas, que resultam na formação de peptídeos biologicamente ativos, os quais, ao interagirem com receptores específicos, acabam auxiliando na regulação deste sistema como um todo. Neste sentido, os mecanismos que controlam a formação, a degradação ou a ação da Ang II em um determinado tecido são fundamentais na determinação dos efeitos fisiológicos ou patológicos deste peptídeo no organismo (Santos et al., 2008).

A visão clássica deste sistema hormonal tem como primeiro componente a renina, uma enzima proteolítica sintetizada e estocada nas células justaglomerulares, a qual é secretada em situações de hipotensão e hipovolemia. A renina cliva seu substrato, o angiotensinogênio, o qual é sintetizado e secretado principalmente pelo fígado, gerando o decapeptídeo Angiotensina I (Ang I). Este decapeptídeo é posteriormente convertido em um octapeptídeo, a Ang II, ao ser clivado pela Enzima Conversora de Angiotensina (ECA), presente principalmente nas células endoteliais da circulação pulmonar. As ações clássicas da Ang II atuam no sentido de inverter a hipovolemia e a hipotensão, que são os principais responsáveis pela ativação desta cascata de eventos, a qual excerce seus efeitos através de dois receptores distintos, 0 receptor de Ang II do tipo 1 (AT1) e do tipo 2 (AT2) (Warner et al., 2004).

No final da década de 80, a existência de SRA locais, ou teciduais, foi descrita pela primeira vez. Com o desenvolvimento de técnicas mais sofisticadas de biologia molecular tornou-se então possível comprovar a existência do RNA mensageiro (RNAm) e da proteína dos diversos 
componentes do SRA em vários tecidos. Baseado nessas evidências, Dzau (1986) propôs o conceito de SRA local ou tecidual, o qual é capaz de gerar Ang II independentemente do SRA clássico, e encontra-se presente no coração e em células cardíacas isoladas (Re, 2004). Desta forma, a geração de Ang II que ocorre na circulação é complementada pelos SRA locais, os quais têm importantes funções homeostáticas e, por vezes, implicações patológicas.

Até o presente momento, dois receptores contendo sete domínios transmembranares e acoplados à proteína $G$ são descritos como mediadores das ações exercidas pela Ang II, o AT1 e o AT2. O receptor AT1 é uma proteína integral de membrana, responsável por mediar a maioria dos efeitos fisiológicos e hipertróficos induzidos pela Ang II, sendo considerado por muitos pesquisadores como um ponto-chave de controle dos efeitos locais exercidos por esse peptídeo (Mehta e Griendling, 2007). Este é responsável por induzir respostas inflamatórias envolvidas com estresse oxidativo, promover efeitos cronotrópicos e inotrópicos positivos no coração, induzir apoptose, além de ativar vias relacionadas ao crescimento e proliferação celular, que acabam por culminar com a hipertrofia cardíaca (Dorn, 2009).

O receptor AT2 apresenta pequena homologia em relação ao receptor AT1 quanto à sequência de aminoácidos (Volpe et al., 2003). Estes receptores são altamente expressos durante o período fetal, e logo após o nascimento têm a sua expressão drasticamente reduzida, ficando restrita a poucos órgãos, incluindo os do sistema cardiovascular (Huang et al., 1996; Bedecs et al., 1997). Ao contrário do receptor AT1, o papel fisiológico do receptor AT2 ainda é muito controverso. Apesar da visão clássica do receptor AT2 ser atribuída à inibição do crescimento (Horiuchi et al., 1999), recentemente, alguns estudos demonstram que sua expressão tem seus níveis aumentados diante de patologias que promovem o remodelamento cardíaco (Kim e Iwao, 2000; Zhu et al., 2003; Carneiro-Ramos et al., 2010). Dessa forma, com base nesses trabalhos recentes que demonstram que o receptor AT2 parece estar envolvido em situações de injúrias cardiovasculares, afirmar que o receptor AT2 seja importante única e exclusivamente ao longo do período fetal parece estar descartado, e inúmeros estudos vêm se propondo a investigar o seu papel, mais profundamente, também na fase adulta. 
Como citado previamente, alguns trabalhos recentes demonstraram que componentes do SRA cardíaco estão significativamente alterados quando em situações de aumento (Anjos-Ramos et al., 2006; Diniz et al., 2007) e diminuição (Carneiro-Ramos et al., 2007) dos níveis plasmáticos dos hormônios tiroideanos, sendo que essas alterações afetam tanto a estrutura (Hu et al., 2003), como a função cardíaca em geral (Hu et al., 2005; CarneiroRamos et al., 2006). Assim, uma estreita relação entre os HT e a ativação de componentes do SRA no sistema cardiovascular vem sendo demonstrada em diversos estudos. Os resultados destes trabalhos mostram que o T3 estimula diretamente a expressão gênica de renina, tanto in vivo como in vitro, além de aumentar a síntese e secreção de angiotensinogênio, e alterar a expressão dos receptores de Angiotensina II (Ang II) (Sernia et al., 1993; Kobori et al., 1997; Ichihara et al., 2001). Nesse contexto, temos ainda que a hipertrofia cardíaca mediada por elevados níveis de HT encontra-se associada a um aumento, em torno de $50 \%$, da expressão do receptor AT2; e que este, quando bloqueado pela administração de PD123319, previne em 40\% o aumento da massa muscular cardíaca (Carneiro-Ramos et al., 2010). Ainda, a utilização de inibidores específicos de componentes do SRA, como antagonista do receptor AT1 ou inibidor da ECA (Hu et al., 2003) foi capaz de atenuar o aumento da massa muscular cardíaca induzida pelo HT in vivo e in vitro (Diniz et al., 2009).

Embora, como explicitado anteriormente, tenhamos na literatura um corpo de resultados suficientemente grande que nos permite concluir haver uma interação entre esses dois sistemas endócrinos (SRA e HT) e isso pareça estar bem estabelecido na hipertrofia que se desenvolve no hipertiroidismo, em outros modelos de injúria cardíaca, como ocorre no modelo de isquemia/reperfusão, o papel destes hormônios parece não estar muito bem definido ainda.

\subsection{Isquemia/Reperfusão (I/R) e cardioproteção}

Doenças cardiovasculares, entre elas aquelas que culminam com a deficiência de irrigação do tecido levando ao infarto do miocárdio, correspondem ainda nos dias de hoje a uma das principais, se não a principal, causa de óbitos na população em geral, segundo a Organização Mundial de Saúde. 
A isquemia miocárdica é resultante de um comprometimento do fluxo sanguíneo coronariano, gerado a partir de um desequilíbrio entre a oferta e a demanda de oxigênio. Em teoria o processo é muito simples, a falta de oxigenação e de substratos metabólicos adequados diminui rapidamente a energia disponível para a célula, levando à lesão celular, que pode ser de natureza reversível ou irreversível. Na prática, o processo é muito complexo, uma vez que a extensão da lesão é determinada por vários fatores, como: gravidade da isquemia (baixo fluxo versus fluxo zero), duração da isquemia, seqüência temporal da isquemia (isquemia curta seguida de isquemia longa), mudanças no ambiente físico e metabólico (normotermia versus hipotermia; conteúdo de glicogênio no miocárdio antes da isquemia, composição do perfusato), bem como a resposta inflamatória (Cokkinos et al., 2006).

A reperfusão, por sua vez, embora represente um pré-requisito para a sobrevivência do tecido, pode, entretanto, promover um aumento das lesões celulares que já ocorreram durante a isquemia. Este fenômeno denominado de "lesão de reperfusão" pode levar à morte celular do miocárdio, a qual pode ocorrer por necrose ou por apoptose, sendo que ambas parecem compartilhar mecanismos comuns em seus estágios iniciais. A intensidade do estímulo é o que irá determinar qual dessas formas é mais prevalente, sendo que as duas formas de morte celular ocorrem em ambientes experimentais de isquemia e reperfusão (Cokkinos at al., 2006).

Assim, a Isquemia-Reperfusão (I/R) vem sendo considerada uma importante causa de injúria cardíaca, uma vez que evidências clínicas e experimentais demonstram que o subsequente restabelecimento do fluxo sanguíneo, após um período de isquemia, pode trazer danos ainda piores para o tecido cardíaco do que o próprio evento isquêmico per se. Como exemplo temos que essa restauração "caótica" do fluxo tissular, conhecida como fenômeno do não-refluxo, resulta em um círculo vicioso de disfunção endotelial vascular, redução da perfusão local, ruptura da membrana celular, edema celular maciço, lise celular e fragmentação, resposta inflamatória, entre outros (Evoara et al., 1996; Cokkinos at al., 2006).

Embora sejam bem caracterizados os eventos que levam à injúria de I/R, o coração possui mecanismos intrínsecos contra essas lesões, as quais 
são induzidas por breves episódios isquêmicos (pré-condicionamento isquêmico). Como exemplos de mecanismos celulares envolvidos nestas circunstâncias tem-se a ativação de proteínas envolvidas em diferentes vias de sinalização intracelular, como a enzima fosfoquinase $C$ (PKC), a quinase glicogênio sintase $3 \beta$ (GSK3 $\beta$ ) e a proteína quinase ativada por adenosina monofosfato (AMPK) (Hausenloy et al., 2006). Esta última, AMPK, corresponde a um importante sensor regulador do status de energia celular, e é ativada em resposta ao estresse isquêmico (Young, 2008). Em corações não isquêmicos a ação da AMPK é decorrente da produção de espécies reativas de oxigênio. Estas, embora quando em excesso possam levar a efeitos deletérios ao tecido, por outro lado, são determinantes e necessárias para a ativação da AMPK (Leon $\mathrm{H}$, 2004). Quando a AMPK é ativada em resposta à isquemia, tem o potencial de aumentar o suprimento energético do miocárdio através da glicólise. Com o aumento da captação de glicose durante a reperfusão, esta proteína passa a exercer, deste modo, um importante efeito cardioprotetor. Assim, a ativação da AMPK desempenha um papel essencial no metabolismo cardíaco favorecendo a proteção do miocárdio após o estresse de I/R (Morrisson, 2011).

O papel cardioprotetor da AMPK pode ser evidenciado em diferentes estudos da literatura. Corações de camundongos transgênicos que expressam uma forma truncada (não ativa) da AMPK, e que foram submetidos a $1 / R$, apresentaram um significativo prejuízo da captação de glicose, glicólise e oxidação de ácidos graxos (Russell, 2004). Ainda, a deleção do gene de MIF (macrophage migration inhibitory factor), um ativador da AMPK, promoveu aumento da lesão cardíaca pós $\mathrm{I} / \mathrm{R}$, em decorrência da baixa captação de glicose, o que levou à diminuição da função contrátil dos cardiomiócitos na recuperação pós-isquêmica, acentuando os efeitos do infarto do miocárdio (Luptak et al., 2007; Miller et al., 2008; Ma et al., 2010). Além disso, já foi demonstrado que a redução na atividade da AMPK levou a comprometimento da função cardíaca, manifestada por diminuição de recuperação pós-isquêmica e aumento da apoptose no miocárdio (Russell et al., 2004).

Os mecanismos intracelulares relacionados à função de proteção desenvolvida pela AMPK após a isquemia do miocárdio estão ainda sendo 
investigados. No entanto, alguns estudos sugerem que a AMPK possui a capacidade de regular a translocação de GLUT4 (transportador de glicose tipo 4) para o sarcolema. Ainda, como a AMPK pode fosforilar a enzima sintase de óxido nítrico endotelial (eNOS) no resíduo de serina-1177, parte de sua ação cardioprotetora pode ocorrer através da via do óxido nítrico (Li et al., 2004). Por outro lado, outras investigações têm mostrado que a AMPK pode ativar a p38 MAPK (proteína quinase ativada por mitógeno) que, por sua vez, aumenta a captação de GLUT4 e a translocação de glicose para o miocárdio (Li et al., 2005).

Embora os trabalhos apresentados anteriormente apontem para um importante efeito cardioprotetor da AMPK, estudos mostram que a ativação da AMPK também pode estimular a ativação da oxidação de ácidos graxos, os quais podem aumentar a produção de prótons e diminuir a eficiência cardíaca, com concomitante inibição da oxidação da glicose. Desta forma, com vista a esses efeitos duais da AMPK nas vias metabólicas, canais iônicos, síntese protéica e função celular, tem-se claro o importante e complexo papel que esta proteína apresenta no modelo de I/R (Dycy et al., 2006).

Ao longo dos últimos anos, os estudos sobre fenótipos de maior tolerância contra a isquemia e reperfusão tornou-se uma importante ferramenta na busca de evidências sobre a resposta adaptativa do coração a um estresse isquêmico. Vários paradigmas de cardioproteção foram identificados e são extensivamente estudados na esperança de encontrar novos alvos terapêuticos para o miocárdio isquemiado. Sabe-se que alguns hormônios desempenham um papel importante na resposta do coração à isquemia. Neste contexto, as alterações hormonais têm sido investigadas na tolerância do miocárdio ao estresse isquêmico (Pantos et al., 2004).

Vale ressaltar que a sinalização intracelular da hipertrofia cardíaca induzida pelos Hormônios Tiroideanos (HT) é semelhante àquela de combate ao estresse. Vários genes que codificam proteínas reguladoras e estruturais no coração são modulados pelos $\mathrm{HT}$ e se relacionam não somente com a hipertrofia, mas também com 0 aumento da contratilidade cardíaca, vasodilatação e angiogênese, prevenção da fibrose e modulação do metabolismo lipídico (Pantos et al., 2004). Neste contexto, evidências 
experimentais mostram que corações tratados de forma aguda com tiroxina (Liu et al., 1998) ou pré-tratados por duas semanas com este hormônio resultam em aumento da recuperação da função cardíaca, quando submetidos à ausência de fluxo global de isquemia seguida de reperfusão, apresentando dessa forma um papel cardioprotetor. (Buser et al., 1990; Pantos et al., 2001).

Assim, os mecanismos pelos quais os HT exercem seu efeito cardioprotetor estão ainda sob intensa investigação. O tratamento crônico com estes hormônios tem sido associado a alterações na expressão de moléculas cardioprotetoras importantes como a proteína quinase $C$ (PKC). O papel cardioprotetor da PKC tem sido documentado em vários estudos, sendo que sua superexpressão em cardiomiócitos resulta na ativação de p38 MAPK, o que contribuiria para a regulação negativa da isquemia (Saurin et al., 2000). Além disso, a PKC pode ainda fosforilar moléculas cardioprotetoras, como a proteína de choque térmico 27 (Hsp27). O aumento da expressão e da fosforilação da Hsp27, especialmente na fração do citoesqueleto, já foi evidenciado em corações de ratos hipertireoideos (Maizels et al., 1998).

O SRA também apresenta um importante papel regulador tanto no modelo de I/R como em outros modelos de injúria cardíaca (Dostal et al., 1999). A Ang II pode pré-condicionar o coração contra o infarto local através da ativação ou inibição de seus receptores. Neste sentido, Yoshiyama e cols (1994) demonstraram que a inibição do receptor AT1 (TCV-116), por uma semana antes da $I / R$, reduziu a injúria de reperfusão e melhorou a função cardíaca em corações perfundidos. Neste mesmo modelo, porém, com o uso de outro bloqueador de AT1 (losartan) foi possível observar também uma atenuação da disfunção mecânica do coração após a isquemia (Yang et al., 1997). Este efeito foi igualmente observado quando o pré-tratamento com losartan foi realizado entre 4-6 horas antes de isolar o coração (Yang et al., 1998). No entanto, ao ser este inibidor perfundido nas coronárias, 5 minutos antes da isquemia, houve piora da eficiência cardíaca (Xu et al., 2002). Assim, no modelo de $\mathrm{I} / \mathrm{R}$, os resultados da inibição do receptor AT1 são ainda contraditórios e parecem estar relacionados com o tempo em que esta inibição é realizada. 
Já no que diz respeito ao papel do receptor do tipo AT2 neste modelo de $\mathrm{I} / \mathrm{R}$, os resultados são ainda mais escassos. Estudos anteriores demonstraram que o processo de $\mathrm{I} / \mathrm{R}$ em corações isolados de ratos diminui a expressão do receptor AT2 e leva a um prejuízo funcional, sendo que o bloqueio seletivo deste receptor, realizado $5 \mathrm{~min}$ antes do processo isquêmico através da perfusão das coronárias com PD-123,319, aumenta a expressão protéica de AT2, ocasionando melhora na recuperação da função cardíaca (Przyklenk et al., 1993; Xu et al., 2002). Ainda, camundongos geneticamente modificados que não expressam o receptor AT2 mostraram redução da sobrevivência e desenvolvimento de uma dilatação do ventrículo esquerdo após infarto do miocárdio, induzido através da oclusão da artéria coronária descendente anterior esquerda. $O$ estudo conclui que os mecanismos relacionados ao papel cardioprotetor do receptor AT2 ainda não foram elucidados, embora exista uma possível relação entre o aumento da expressão deste receptor e a proteção do coração após o processo isquêmico (Oishi, 2003).

Se por um lado esses estudos indicam um importante papel do AT2 ligado à cardioproteção, por outro, este receptor mereceu recentemente o editorial da revista Cardiovascular Research, a qual teve como título: "Programação fetal revela o lado negro do receptor AT2" (Thornburg, 2011). Nesta edição um dos estudos mostrou que a hipóxia fetal promove programação gênica, com consequente aumento da expressão do receptor AT2 na vida adulta, levando o miocárdio a uma maior vulnerabilidade à isquemia cardíaca, decorrente da hipóxia fetal. Desta forma, o aumento da expressão do receptor AT2 resultou em piora da função cardíaca após o evento isquêmico, a qual foi prevenida com a administração do inibidor específico do receptor, PD123,319 (Xue et al., 2011). Estes resultados colocam em cheque a "boa reputação" até então mostrada do receptor AT2, trazendo novos questionamentos e instigando ainda mais a busca sobre os mecanismos de proteção miocárdica relacionados a este receptor.

Embora alguns trabalhos da literatura tenham investigado o papel do receptor AT1 no modelo de $\mathrm{l} / \mathrm{R}$ no hipertiroidismo, demonstrando que a inibição deste recebtor não abole o efeito cardioprotetor do HT na recuperação da função cardíaca (Pantos et al.,2005), o papel e a importância do receptor AT2 é 
totalmente desconhecida neste modelo experimental. Diante disto, é possível hipotetizar que um dos mecanismos que esteja relacionado ao efeito cardioprotetor do HT aumentando a contratura isquêmica e melhorando a recuperação da função cardíaca pós-isquemia ocorra com a participação do receptor AT2, uma vez que estes se encontram, como citado anteriormente, aumentados em condições de hipertiroidismo. 


\section{JUSTIFICATIVA}

A restauração do fluxo sanguíneo cardíaco após um período de isquemia pode resultar em diversos efeitos deletérios, levando a disfunções celulares e teciduais. Mesmo diante da injúria de $\mathrm{l} / \mathrm{R}$ o coração possui mecanismos intrínsecos contra estas lesões, dentre eles mecanismos celulares complexos que envolvem várias diferentes vias de sinalização, como ocorre com a via relacionada à proteína quinase ativada por adenosina monofosfato (AMPK).

O HT exerce um efeito cardioprotetor bastante similar àquele observado com o pré-condicionamento, ou seja, aumenta a contratura isquêmica e melhora a recuperação da função cardíaca pós-isquemia no modelo de coração isolado (Pantos et al., 2002). Em situações de elevação dos níveis plasmáticos de $\mathrm{HT}$, os quais deflagram um processo de instalação de hipertrofia cardíaca, nós demonstramos recentemente existir um acentuado aumento da expressão dos receptores de angiotensina do tipo II (receptor AT2) no tecido cardíaco (Carneiro-Ramos et al., 2010). Estudos demonstram que os receptores AT2, por sua vez, estão relacionados a uma melhora na recuperação da função cardíaca (Przyklenk et al., 1993; Yi Xu et al., 2002) e apontam para uma possível relação entre o aumento da expressão de AT2 e um importante papel de cardioproteção.

Diante disto, é plenamente justificável avaliar se, pelo menos em parte, o papel cardioprotetor exercido pelo HT ocorre ou não com a participação do receptor AT2. Além disso, considerando que a via da AMPK é acionada em resposta ao estresse isquêmico, torna-se de grande interesse avaliar o importante e complexo papel que esta proteína apresenta neste modelo de l/R. 


\section{OBJETIVOS}

\subsection{Objetivo Geral}

Diante do exposto previamente, o objetivo geral do presente estudo foi avaliar a participação do receptor de Angiotensina II, do tipo 2 (AT2), na resposta cardioprotetora induzida pelo Hormônio Tiroideano no modelo de Isquemia-Reperfusão, em corações isolados de ratos.

\subsection{Objetivos Específicos}

- Avaliar o papel do receptor AT2 na recuperação da função cardíaca pós-isquemia, em situações de eutiroidismo e hipertiroidismo.

- Avaliar a possível contribuição da via de sinalização da proteína quinase ativada por adenosina monofosfato (AMPK), a qual corresponde a um importante sensor regulador do status de energia celular, e é acionada em resposta ao estresse isquêmico. 


\section{MATERIAL E MÉTODOS}

\subsection{Animais}

1. Foram utilizados ratos adultos (Rattus norvegicus) da linhagem Wistar, com peso entre 250 e $280 \mathrm{~g}$, provenientes do Biotério Central do Instituto de Ciências Biomédicas - Universidade de São Paulo (USP) e mantidos no Biotério do Departamento de Anatomia (ICB III -USP). Os animais foram acondicionados em gaiolas plásticas e mantidos em sala climatizada com temperatura $(24 \pm 1 \stackrel{\circ}{\circ}$ ) e umidade (aproximadamente $60 \%$ ) controladas e ciclo claro/escuro de 12 horas. Os ratos tiveram livre acesso à água e ração.

2. Ratos foram usados neste estudo, porque a função cardíaca nestes animais é suficientemente similar à de humanos, o que faz deste um modelo animal apropriado para estudos que serão relevantes para as condições fisiológicas humanas.

3. Os animais foram eutanasiados por decapitação. Eles não foram anestesiados antes da decapitação, porque o uso de anestésicos induz mudanças nas concentrações bioquímicas basais e poderia até mesmo obscurecer efeitos de testes farmacológicos (Kilbourn et al., 2007).

4. Este projeto está de acordo com os princípios éticos de Experimentação Animal adotado pelo Colégio Brasileiro de Experimentação Animal (COBEA) e foi aprovado em 09/02/2010 pela Comissão de Ética em Experimentação Animal (CEEA), em adendo ao Certificado 114/04/CEEA, datado de 16/12/2004.

\subsection{Grupos Experimentais}

Os corações dos diferentes grupos experimentais foram rapidamente retirados, montados no sistema de coração isolado, como descrito posteriormente, e submetidos ao modelo de Isquemia/Reperfusão.

Quatro diferentes grupos experimentais foram realizados:

Grupo 1: Ratos eutireoideos (controle);

Grupo 2: Ratos eutireoideos tratados durante 14 dias com inibidor do receptor AT2 (PD123,319), o qual foi infundido no animal através da utilização de bombas osmóticas de infusão contínua (Alzet).

Grupo 3: Ratos hipertireoideos tratados por 14 dias com T3. 
Grupo 4: Ratos hipertireoideos tratados por 14 dias com T3 e inibidor do receptor AT2 (PD123,319).

\subsubsection{Indução ao Hipertireoidismo}

O hipertireoidismo foi induzido nos ratos pela administração de triiodotironina (T3 - T2877, Sigma, St Louis, MO) intra peritoneal (ip.) duas vezes ao dia, em uma dose final correspondente a vinte vezes a dose fisiológica (T3, $7 \mu \mathrm{g} / 100 \mathrm{~g}$ p.c /dia) do animal, durante 14 dias. O T3 foi solubilizado em $\mathrm{NaOH}(0.34 \mathrm{M})$ e para administração no rato foi diluído em salina $0,09 \%$. Os animais do grupo controle foram tratados com injeções ip. do mesmo veículo utilizado no grupo T3. Este modelo de hipertiroidismo foi escolhido uma vez que já vem sendo utilizado em trabalhos prévios de nosso grupo.

\subsubsection{Inibição do receptor AT2}

A inibição do receptor AT2 foi realizada por meio da utilização de bombas

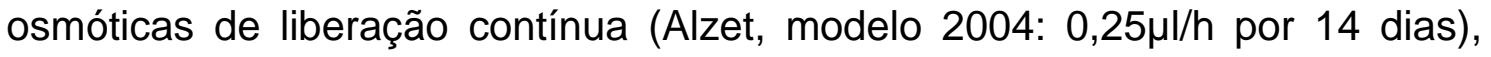
implantadas na região dorsal, abaixo da pele, contendo o inibidor PD123319. A dose utilizada foi de $10 \mathrm{mg} / \mathrm{kg}$ (Carneiro-Ramos et al., 2010).

A droga foi solubilizada em água ultra pura. As bombas osmóticas foram deixadas de molho em salina a uma temperatura de $37^{\circ} \mathrm{C}$ overnight, seguindo instruções do fabricante. Antes de injetar a droga na bomba osmótica, a mesma foi pesada, e o peso inicial utilizado para calcular o volume preenchido na bombinha, assegurando pelo menos $90 \%$ do volume total que é $246,9 \mu$ l.

\subsection{Dosagem Sérica dos Hormônios Tiroideanos}

Após o período experimental, os ratos foram eutanasiados, o sangue total coletado foi submetido a centrifugação de $3000 \mathrm{rpm}$ por 15 minutos a temperatura de $4 \stackrel{\circ}{\circ}$. Após esta etapa o soro foi isolado e ultilizado para dosagens de T3 e T4 Total, utilizando-se o kit de radioimunoensaio comercial (T4 total COAT-A-COUNT TKT41 e T3 total COAT-A-COUNT TKT31, Siemens, EUA). Para os ensaios, curvas-padrão foram construídas e a contagem foi realizada pelo Contador Gama da Sala Multiusuários do Departamento de 
Anatomia do Instiututo de Ciências Biomédicas III da USP (Modelo 1470 Wizard Automatic Gama Counter, PerkinElmer, EUA).

\subsection{Coleta de tecidos para cálculo da relação entre peso úmido e seco}

Após o tratamento por 14 dias, os ratos foram eutanasiados e fígado e pulmão esquerdo dos animais de cada grupo experimental foram coletados e congelados a $-80 \quad \stackrel{\circ}{\mathrm{C}}$ para posteriormente serem pesados. Após descongelamento, foi retirado um pedaço do tecido (pulmão e fígado) que foi considerado como peso úmido. O passo seguinte foi submeter estes tecidos a uma temperatura de $50^{\circ} \mathrm{C}$ em uma estufa por $24 \mathrm{~h}$ para secagem do tecido e cálculo do peso seco. Esse cálculo nos permite ter uma idéia do índice de congestão pulmonar e hepático, o que, indiretamente, pode ser associado ao processo de insuficiência cardíaca congestiva.

\subsection{Preparação do Coração Isolado}

Os corações foram excisados e limpos em solução modicada de KrebsHenseleit $(\mathrm{KH})$ contendo: $\mathrm{NaCl}(118 \mathrm{mM}), \mathrm{KCl}(4,7 \mathrm{mM}), \mathrm{CaCl}_{2}(1,5 \mathrm{mM})$, $\mathrm{MgSO}_{4}(1,66 \mathrm{mM}), \mathrm{NaHCO}_{3}(24,88 \mathrm{mM}), \mathrm{KH}_{2} \mathrm{PO}_{4}(1,18 \mathrm{mM})$, dextrose 2g/L e água ultra pura, $\mathrm{pH} 7,4 . \mathrm{O}$ pH foi ajustado por contínua gaseificação com uma mistura de $95 \%$ oxigênio e $5 \%$ de gás carbônico. O perfusato foi prepado na hora do experimento e filtrado (Swinnex® $47 \mathrm{~mm}$, poro da membrana $0,22 \mu \mathrm{M}$ ) imediatamente antes da perfusão.

Os corações foram rapidamente montados no Sistema de Langendorff (Radnoti-ADInstruments) (Figura 1) e perfundidos retrogradamente de acordo com o Método de Langendorff (Skrzypiec-Spring et al., 2007), através da aorta ascendente, com solução $\mathrm{KH}$, a $37^{\circ} \mathrm{C}$, a fluxo constante $(8-10 \mathrm{ml} / \mathrm{min})$ e sem recirculação. Quando colocados no aparato, os corações ficavam imersos em uma banho com a mesma solução de perfusão, com temperatura e com pH controlados. Menos de 1 minuto foi o tempo utilizado para decapitar o animal e realizar a pesagem do coração e a canulação da aorta no sistema.

Todos os corações, ao serem colocados no sistema, tiveram o ápice do ventrículo esquerdo perfurado com agulha introduzida através da valva mitral, pelo átrio esquerdo (Fallen, 1967). Os corações de todos os grupos foram 
submetidos ao processo de Isquemia/Reperfusão obedecendo a um protocolo experimental de 30 minutos de estabilização, 20 minutos de isquemia global (fluxo=0) e posterior restauração do fluxo, com 45 minutos de reperfusão, de acordo com Pantos et al. (2005) (Figura 2). Ao término do experimento o coração foi pesado, os átrios foram desprezados e os ventrículos separados em direito e esquerdo + septo e armazenados a $-80{ }^{\circ} \mathrm{C}$ para posterior processamento das amostras.

Figura 1 - Sistema de Langendorff (Radnoti-Adinstruments).

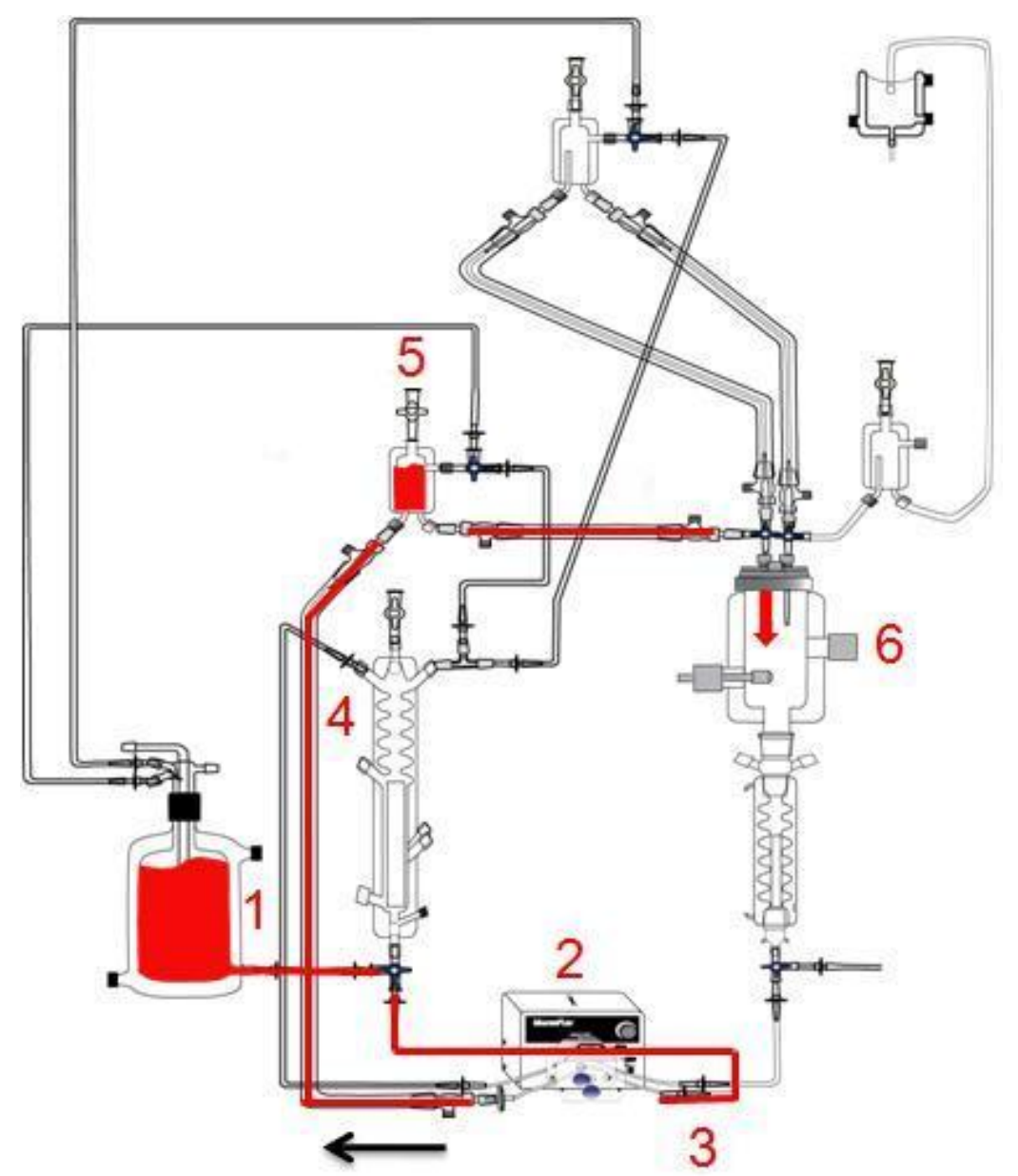

Neste sistema, a solução de perfusão é mantida a $37^{\circ} \mathrm{C}$ em constante gaseificação em um reator (1). Esta solução é conduzida à câmara de perfusão por bomba peristáltica (2). Antes de chegar ao coração,esta passa por um "papa-bolhas" que assegura a retirada de qualquer bolha do sistema (5). Após passar pelo coração a solução é desprezada (6).

Fonte: Radnoti-Adinstruments 
Figura 2 - Protocolo experimental de Isquemia e Reperfusão utilizado no estudo.

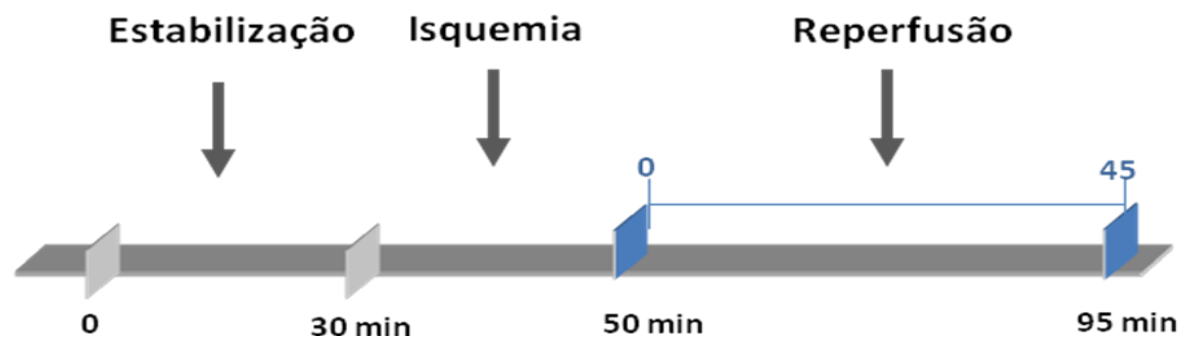

Este protocolo foi adaptado de Pantos et al. (2005) contendo 30 minutos de estabilização, 20 minutos de isquemia global e posterior restauração do fluxo, com 45 minutos de reperfusão.

Fonte: Tavares (2012).

\subsection{Aquisição de dados}

Alguns parâmetros foram aferidos:

- Pressão Desenvolvida pelo Ventrículo Esquerdo (LVDP), que consiste na diferença entre a Pressão Sistólica (LVSP) e a Pressão Diastólica Final do Ventrículo Esquerdo (LVEDP);

- $+\mathrm{dP} / \mathrm{dt}$ (1 ${ }^{\underline{a}}$ derivada positiva das pressões) e - $\mathrm{dP} / \mathrm{dt}$ (1 ${ }^{\underline{a}}$ derivada negativa das pressões), que são índices que indicam a capacidade de gerar pressão ou contratilidade e a velocidade de relaxamento do coração, respectivamente.

- Frequência Cardíaca e Pressão de Perfusão.

Todos estes parâmetros foram monitorados continuamente por um sistema de registro (PowerLab-Lab Chart 7, ADInstruments, EUA).

\subsubsection{Função ventricular esquerda}

A função ventricular esquerda foi avaliada por um balão intraventricular, como descrito por Fallen et al. (1967). Este método oferece a possibilidade de avaliar com considerável exatidão a força contrátil. Um balão de látex foi inserido no interior do ventrículo esquerdo no $10^{\circ}$ minuto do período de estabilização, através de uma incisão no átrio esquerdo (Figura 3A, B). 0 volume do balão foi ajustado a produzir uma pressão diastólica final de 8-10 $\mathrm{mmHg}$ em todos os grupos, determinando a pré-carga não-fisiológica no início do experimento. $O$ balão, fabricado no laboratório utilizando preservativo nãolubrificado, medindo de 3-5 mm de diâmetro, foi conectado ao transdutor de 
pressão (ADInstruments, EUA) acoplado a um software (LabChart 7.0) para aquisição de dados. Para avaliar a função sistólica do ventrículo esquerdo, foram utilizadas medidas da pressão desenvolvida pelo ventrículo esquerdo (LVDP) (definida como a diferença entre o pico de pressão sistólica do ventrículo esquerdo e a pressão ventricular esquerda diastólica final), pela primeira derivada positiva $(+\mathrm{dP} / \mathrm{dt})$ e negativa $(-\mathrm{dP} / \mathrm{dt})$ da pressão ventricular. $\mathrm{O}$ parâmetro de Frequência Cardíaca também foi aferido através do balonete (Figura 3A, B).

\subsubsection{Eletrocardiograma e Freqüência cardíaca}

Durante a perfusão, eletrodos foram colocados na superfície do coração, no átrio e no ápice cardíaco. Este aparato permitiu avaliar o perfil do sinal elétrico do coração durante todo o experimento, bem como verificar a ocorrência de arritmias e a frequência cardíaca. O monitoramento do ECG e da frequência cardíaca momento a momento durante o experimento é uma importante ferramenta que permitiu avaliar a qualidade da perfusão e 0 processo de Isquemia/Reperfusão.

\subsubsection{Pressão de Perfusão}

A pressão de perfusão do coração foi avaliada por um transdutor de pressão conectado à cânula de perfusão. $O$ perfusato oxigenado supre 0 coração por meio de uma bomba peristática (fluxo pulsátil). O fluxo constante gera uma pressão de perfusão correspondente, porém variável dependendo do estímulo. 
Figura 3 - Representação gráfica e fotográfica do coração no aparato de Langendorff

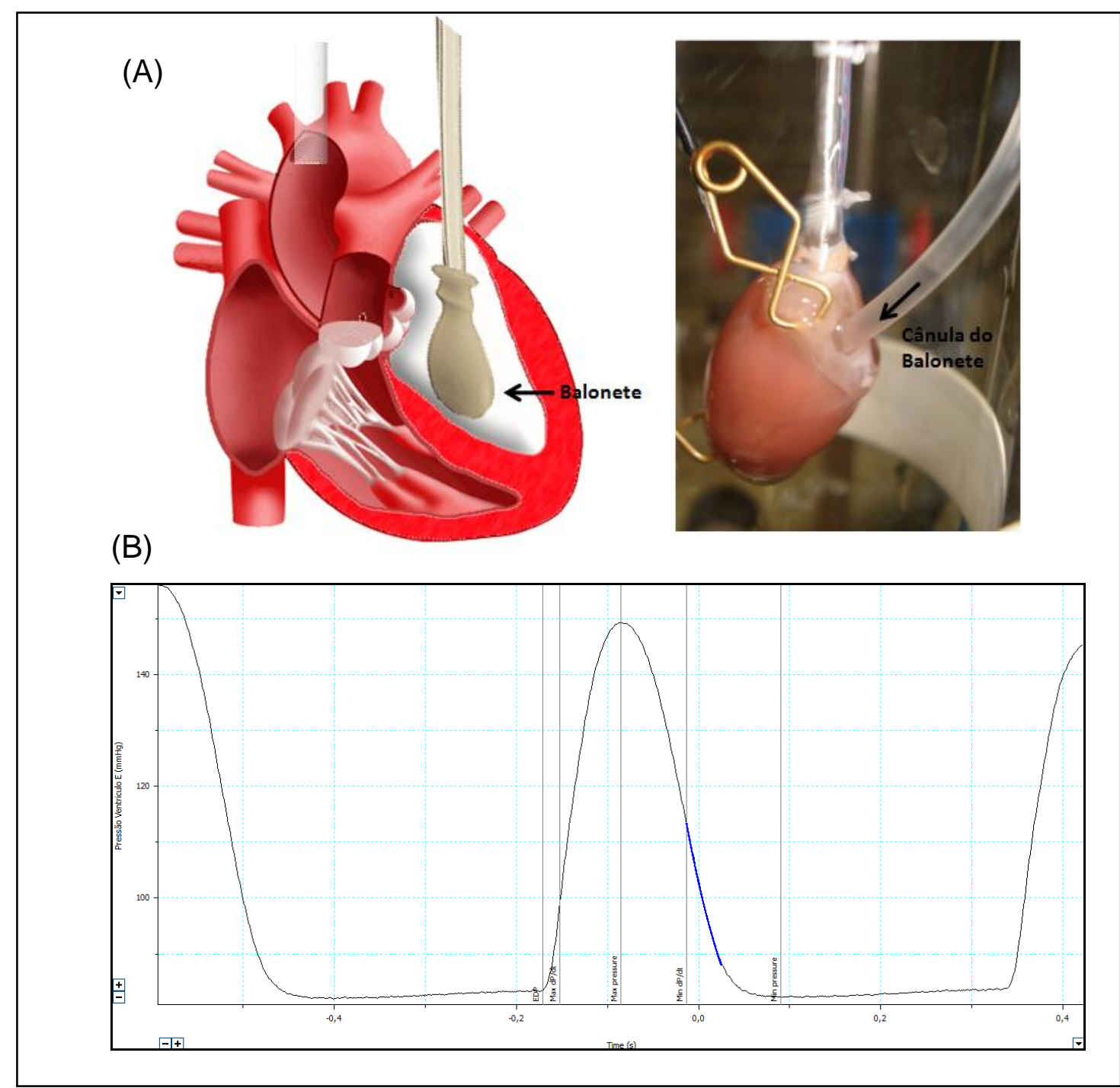

(A). Representação e fotografia mostrando a inserção do balonete no ventrículo esquerdo (VE). Dois eletrodos são fixados (no átrio e no ápice do coração) e um terceiro (eletrodo de referência) é preso à cânula de metal onde o coração está fixado. (B). Representação de um registro da contração isovolumétrica do VE, registrado durante o experimento.

Fonte: Radnoti-Adinstruments; Tavares (2012). 


\subsection{Análise dos níveis de Angiotensina I/II, da expressão dos receptores AT1 e AT2 e da participação da via da AMPK}

Os níveis de Ang I/II, dos seus receptores (AT1 e AT2), da AMPK fosforilada e total e do GAPDH foram avaliados e quantificados por Western Blotting. Foram utilizados anticorpos específicos, cuja procedência e titulação encontram-se descritas na Tabela 1. A escolha do GAPDH como normalizador interno se baseou em trabalhos prévios do laboratório os quais já demonstraram que o T3 não modula a sua expressão.

Após a retirada dos corações, estes tiveram suas câmaras separadas e posteriormente os tecidos foram homogeneizados em tampão de extração (90 $\mathrm{mm} \mathrm{KCl}, 10 \mathrm{mM}$ Hepes, $3 \mathrm{mM} \mathrm{MgCl}{ }^{2+}$, 5mM EDTA, 1\% glicerol, $1 \mathrm{mM}$ DTT, 0,04\% SDS, após acertar o pH 7,4, adicionamos um mix de inibidores de proteases contendo PMSF, ortovanadato, aprotinina, leupeptina, pepstatina). A concentração de proteína foi determinada pelo Método de Bradford (Bradford, 1976). 50 $\mathrm{gg}$ da proteína foram separadas por eletroforese em gel de SDSPoliacrilamida (Sódio Dodecil Sulfato-Poliacrilamida, 15\%), e então transferidas para uma membrana de nitrocelulose (Bio-Rad). A membrana foi marcada com solução de Ponceau para demonstrar se a concentração de proteína era similar nos diferentes poços. Posteriormente, a membrana foi lavada em Tampão Salina Tris Tween-20 (TBS): (50 mM Tris, 150 mM NaCl, pH 7,5 e 2\% Tween20), por 10 min, em temperatura ambiente. As membranas foram então incubadas a $4^{\circ} \mathrm{C}$, overnight, com anticorpo primário específico contra as proteínas de interesse. Após lavar as membranas com TBST para remover o anticorpo primário, os "blots" foram então incubados por $1 \mathrm{~h}$, em temperatura ambiente, com o anticorpo secundário ligado à peroxidase. Após a ligação do anticorpo secundário, foi acrescentada uma solução de ECL (Armesham Biosciences), que, ao reagir com a peroxidase do anticorpo secundário, produziu uma reação quimioluminescente, oxidando um filme de raio-X (T-MAT G/RAFilm - KODAK) e permitindo a identificação de bandas referentes à marcação de proteínas específicas ao anticorpo primário, as quais foram posteriormente quantificadas em um sistema de fotodocumentação (ImageJ). 
Tabela 1 - Lista dos anticorpos primários utilizados para análise de expressão protéica por Western Blooting.

\begin{tabular}{lccc}
\hline Proteínas Analisadas & Origem & Peso Molecular & Titulação \\
\hline p-AMPKa $\left(\right.$ Tre $\left.^{172}\right)$ & Cell Signaling (2531) & $62 \mathrm{kDa}$ & $1: 800$ \\
AMPKa & Cell Signaling (2532) & $62 \mathrm{kDa}$ & $1: 800$ \\
Angiotensin I/II & Santa Cruz (sc-7419) & $60 \mathrm{kDa}$ & $1: 500$ \\
AT2 & Alomone (AAR-012) & $44 \mathrm{kDa}$ & $1: 800$ \\
AT1 & Millipore (AB15552) & $43 \mathrm{kDa}$ & $1: 500$ \\
GAPDH & Santa Cruz (sc-32233) & $37 \mathrm{kDa}$ & $1: 1000$ \\
\hline Fonte: Tavares (2012). & & &
\end{tabular}

Fonte: Tavares (2012).

\subsection{Análise estatística}

Os dados obtidos encontram-se apresentados como Média \pm ErroPadrão da média. $\mathrm{O}$ valor de $\mathrm{n}$ corresponde ao número de animais utilizados em cada grupo experimental. Os resultados foram analisados e comparados utilizando-se a Análise de Variância (ANOVA), seguida do pós-teste de Tukey para análises one-way (Figuras 4, 11,12 e 13) e pós-teste de Bonferroni para análises two-way (Figuras 6, 7, 8, 9 e 10). Valores de $p<0,05$ foram considerados estatisticamente significantes. 


\section{RESULTADOS}

Com base nas considerações prévias, passamos então a apresentar os dados referentes aos parâmetros de função cardíaca, obtidos com essa metodologia frente às nossas condições experimentais, animais submetidos ao hipertiroidismo e tratados com o bloqueador do receptor AT2 (PD123319).

\subsection{Efeito do bloqueio do Receptor AT2 na Hipertrofia Cardíaca induzida por HT}

O modelo de hipertireoidismo experimental, com o uso do T3, na dose utilizada no presente estudo, já foi caracterizado em diversos trabalhos do nosso laboratório. No entanto, iniciamos os experimentos confirmando mais uma vez a eficiência do modelo experimental. Para tal, foi avaliada inicialmente a razão peso do coração pelo comprimento da tíbia, uma vez que esta razão dá uma idéia da hipertrofia cardíaca, característica comumente associada ao tratamento com doses supra-fisiológicas de Hormônio Tiroideano. Conforme pode ser observado, o tratamento com o T3 determinou uma hipertrofia cardíaca com aumento de $25 \%$ da razão peso do coração/comprimento da tíbia, em relação ao grupo controle (Figura 4). Embora o tratamento concomitante com o inibidor do receptor AT2 (grupo PD+T3) não tenha alterado significativamente esse parâmetro, em relação ao grupo T3, nota-se que houve uma tendência à diminuição (de aproximadamente $10 \%$ ) na razão peso coração/comprimento da tíbia. O tratamento com o bloqueador do receptor AT2, por sua vez, não promoveu alteração significativa deste parâmetro.

Ainda com o objetivo de validar o modelo experimental, foi realizada a dosagem sérica dos Hormônios Tiroideanos (T3 e T4 total), cujos valores encontram-se na Tabela 2. Os dados revelam que a indução ao Hipertiroidismo foi eficaz, uma vez que o grupo submetido ao tratamento com T3 mostrou valores de T3 Total significativamente superiores aos do grupo controle (61\%). Um dado interessante é que a inibição do receptor AT2 (grupo PD+T3) foi capaz de prevenir o aumento do T3 Total induzido pelo tratamento singular com o T3, retornando os valores séricos desse grupo a valores do controle. 
Com relação à dosagem sérica do T4 total, pode-se perceber que os grupos que foram tratados com o T3 obtiverem valores insignificantes de T4 total, mostrando então que a alça de retroalimentação negativa existente na regulação dos níveis dos hormônios T3 e T4 estava funcional e, portanto, os animais destes dois grupos apresentavam-se hipertiroideos.

Figura 4 - Análise da razão peso do coração pelo comprimento da tíbia

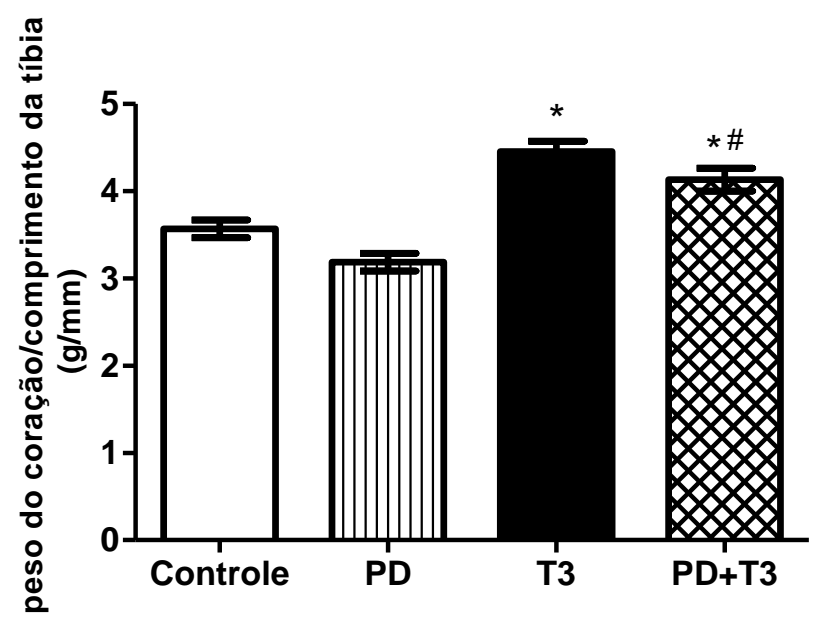

Razão peso do coração/comprimento da tíbia (controle $n=14$; PD $n=15$; T3 $n=9$; $\mathrm{PD}+\mathrm{T} 3 \mathrm{n}=9)$. * vs controle $(p<0,05)$; \# vs PD $(p<0,05)$.

Fonte: Tavares (2012).

Tabela 2 - Dosagem sérica de Hormônios Tiroideanos dos ratos submetidos aos diferentes grupos experimentais.

\begin{tabular}{ccc}
\hline Grupo & T4 Total $(\boldsymbol{\mu g} / \mathbf{d L})$ & T3 Total $(\mathbf{n g} / \mathbf{d L})$ \\
\hline Controle $(n=7)$ & $5,3 \pm 0,59$ & $74,5 \pm 4,3$ \\
PD $(n=7)$ & $5,3 \pm 0,38$ & $60,3 \pm 2.9$ \\
T3 $(n=6)$ & - & $122,7 \pm 9,1^{*}$ \\
PD+T3 $(n=6)$ & - & $59,2 \pm 6,4^{\S}$
\end{tabular}

* vs controle $(p<0,05), \S$ vs T3(p<0,05).

Fonte: Tavares (2012). 


\subsection{Efeito dos tratamentos sobre o teor de água pulmonar e hepático}

Não houve diferença quanto à retenção de líquido pulmonar ou hepático entre os diferentes grupos experimentais, confirmando estudos prévios do grupo e mostrando que a dose e o tempo dos tratamentos não foram suficientes para promover congestão pulmonar ou hepática, geralmente associados à insuficiência cardíaca congestiva (Tabela 3).

Tabela 3 - Avaliação do Peso úmido e Peso seco (em mg) do Pulmão e do Fígado nos diferentes grupos experimentais.

\begin{tabular}{ccc}
\hline Grupo & Pulmão $(\mathbf{m g})$ & Fígado $(\mathbf{m g})$ \\
\hline Controle $(n=5)$ & $44,4 \pm 1,7$ & $35,9 \pm 1,4$ \\
PD $(n=5)$ & $44,2 \pm 1,6$ & $32,7 \pm 0,8$ \\
T3 $(n=5)$ & $46,7 \pm 1,1$ & $39,1 \pm 1,4$ \\
PD+T3 $(n=5)$ & $42,9 \pm 2,4$ & $37,8 \pm 1,1$
\end{tabular}

Fonte: Tavares (2012).

\subsection{Efeito do bloqueio do Receptor AT2 em parâmetros da função} cardíaca, em animais hipertiroideos, frente a situações de $\mathbf{~ / R}$

Com exceção da pressão de perfusão, que foi aferida diretamente por um transdutor localizado acima da cânula de perfusão retrógrada da aorta, os demais parâmetros foram obtidos através do balonete inserido no ventrículo esquerdo, conforme descrito previamente na metodologia. Estes parâmetros foram registrados durante todo 0 experimento e para a avaliação foi selecionado o último minuto do período de estabilização e os tempos de 25, 35 e 45 minutos do período de reperfusão. A figura a seguir representa o registro de um coração do grupo controle, com os parâmetros que foram avaliados durante o experimento (Figura 5). 
Figura 5 - Registro gerado pelo software LabChart 7.0.

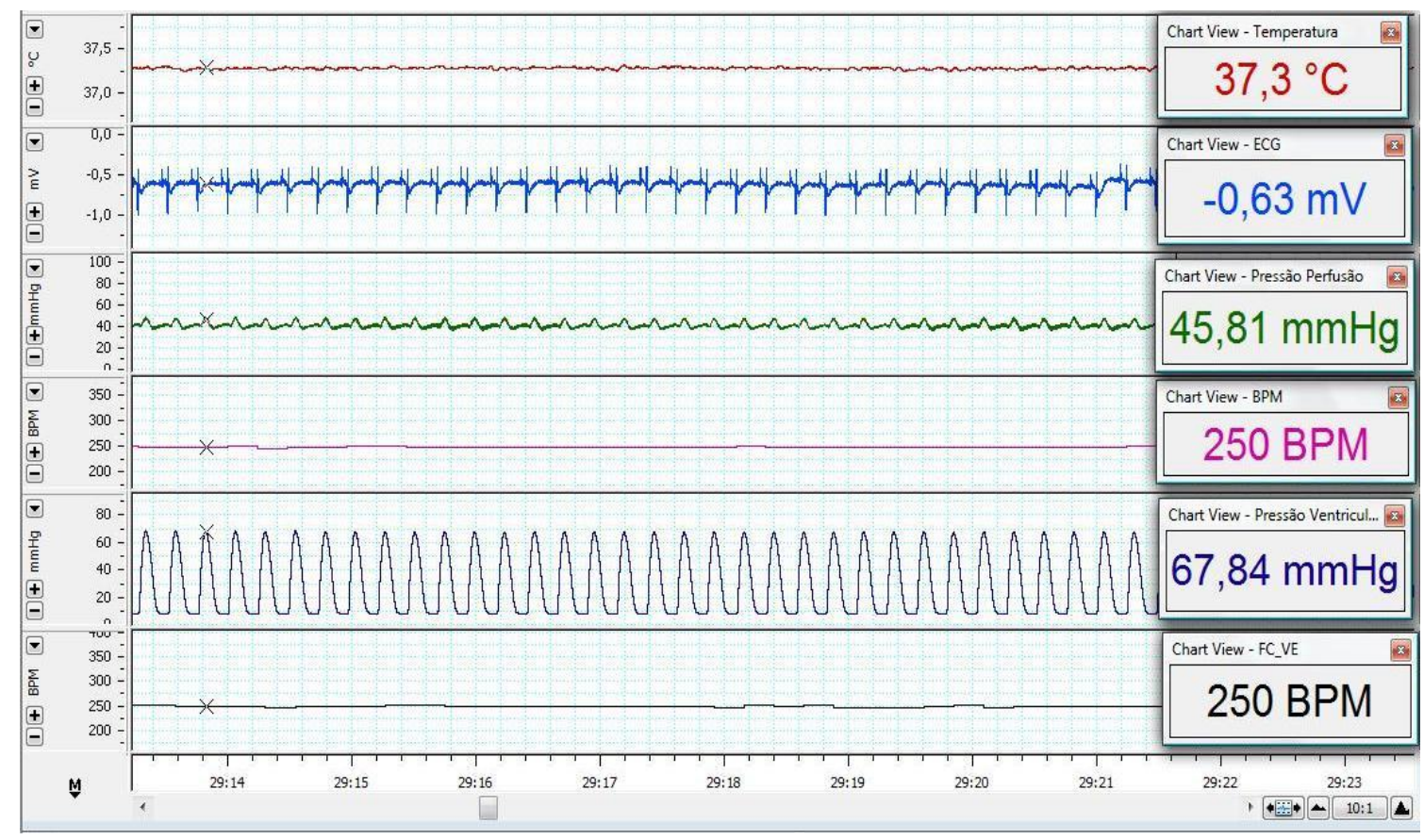

Avaliação dos parâmetros: temperatura, eletrocardiograma, pressão de perfusão, frequência cardíaca e pressão ventricular.

Fonte: Tavares (2012).

\subsubsection{Pressão Desenvolvida pelo Ventrículo Esquerdo (LVDP)}

Um parâmetro de fundamental importância para avaliar a função cardíaca é a LVDP. Para calculá-lo, foi realizada a diferença entre o pico de pressão sistólica e a pressão diastólica final do ventrículo esquerdo. Pode-se observar que durante o período de estabilização, período em que o coração está se aclimatizando à nova situação de perfusão, o grupo PD apresentou uma redução significativa da LVDP de $16 \%$ em relação ao grupo controle $(57,5$ $\pm 2,5$ vs. $66,83 \pm 0,1 \mathrm{mmHg}$ no controle). Ainda neste período, o uso do PD juntamente com o T3 mostrou aumento de $20 \%$ em relação ao grupo que utilizou apenas o PD (69,3 $\pm 1,7$ vs $57,5 \pm 2,8 \mathrm{mmHg}$ no grupo PD).

Após o período de isquemia, momento em que o tecido cardíaco sofreu inúmeras alterações metabólicas na tentativa de manter-se vivo, devido à ausência de oxigênio, o coração foi submetido à reperfusão. $O$ bloqueio do receptor AT2 (grupo PD) não alterou significativamente a LVDP em qualquer dos períodos de reperfusão avaliados (Figura 6). Já o grupo hipertiroideo mostrou um aumento significativo deste parâmetro aos 35 minutos de reperfusão (27\%) (74,9 $\pm 1,7$ vs $59 \pm 5,4 \mathrm{mmHg}$ do grupo controle), o qual foi 
ainda mais acentuado aos 45 minutos de reperfusão (cerca de $35 \%)(74,1 \pm 1,6$ vs. $54,8 \pm 3,7 \mathrm{mmHg}$ no controle).

Em todos os tempos de reperfusão o bloqueio do receptor AT2 foi capaz de prevenir o aumento da LVDP induzido pelo T3 (grupo PD+T3). Aos 25 minutos a LVDP neste grupo (PD+T3) foi cerca de $30 \%$ inferior ao grupo hipertiroideo $(45,3 \pm 2,7$ vs. $68,4 \pm 3,6 \mathrm{mmHg}$ no grupo T3), o mesmo ocorrendo aos 35 minutos (49,9 $\pm 1,3$ vs. $74,9 \pm 1,7 \mathrm{mmHg}$ no grupo T3), e aos 45 min. de reperfusão $(50,2 \pm 1,7$ vs. $74,1 \pm 1,6 \mathrm{mmHg}$ do grupo T3).

Figura 6 - Pressão Desenvolvida pelo Ventrículo Esquerdo (LVDP),

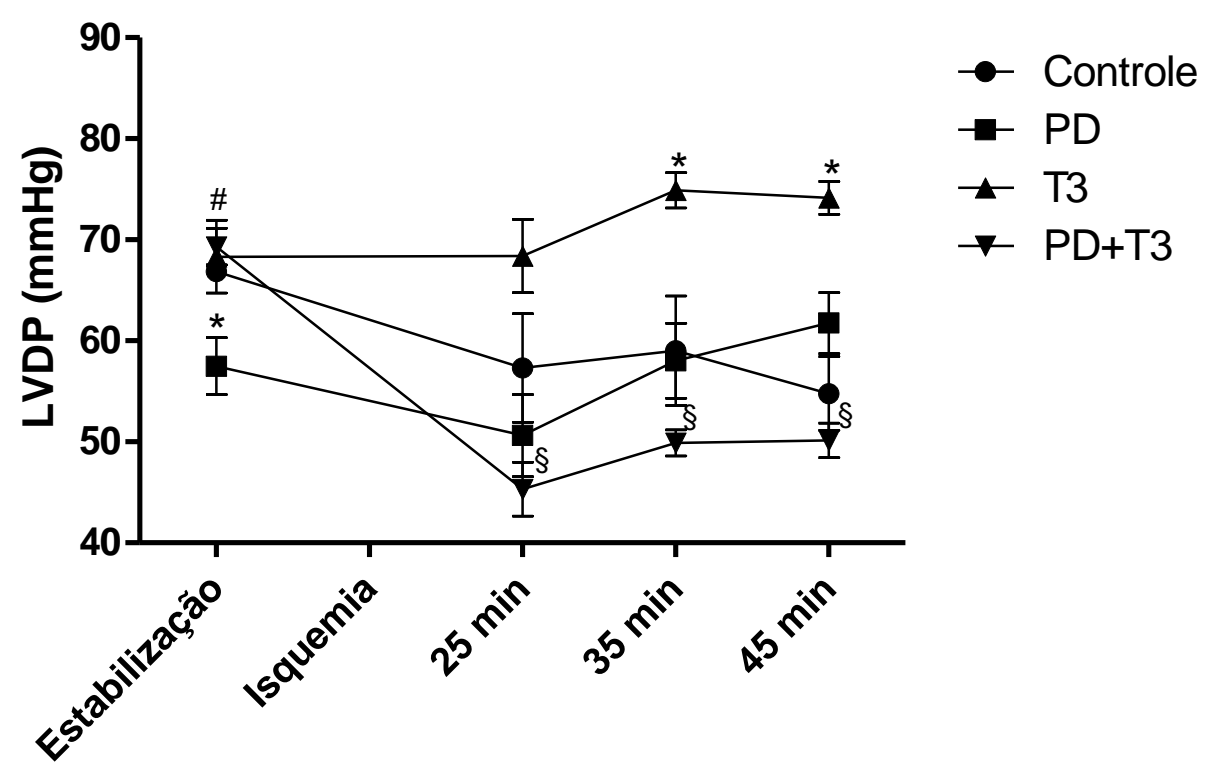

LVDP avaliada nos períodos de: Estabilização, $25 \mathrm{~min}$ de reperfusão, $35 \mathrm{~min}$ de reperfusão e 45 min de reperfusão (controle $n=9 ; P D n=8 ; T 3 n=7 ; P D+T 3 n=7$ ). * vs controle $(p<0,05)$, \# vs PD $(p<0,05)$, $\S$ vs T3 $(p<0,05)$.

Fonte: Tavares (2012)

\subsubsection{Primeira Derivada Positiva das Pressões $(+\mathrm{dP} / \mathrm{dt})$}

A taxa de variação de pressão no tempo (dP/dt), designada habitualmente como $1^{\text {a }}$ derivada temporal da pressão ventricular, é um dos índices utilizados para avaliação da função do ventrículo esquerdo. $A+d P / d t$ é considerada um índice de contratilidade, tornando possível avaliar indiretamente o inotropismo cardíaco, que é a propriedade do coração relacionada à força de contração muscular. 
No período de estabilização, este parâmetro mostrou-se significativamente maior (39\%) nos corações do grupo tratado com T3 $(2851,1$ $\pm 196,2$ vs. $2053,7 \pm 168,2 \mathrm{mmHg} / \mathrm{s}$ no grupo controle). O tratamento dos animais com o bloqueador do receptor AT2 não promoveu alteração nesse parâmetro, quando comparado ao grupo controle. Já quando administrado concomitantemente ao T3 (PD+T3) mostrou-se, como no grupo T3, significativamente maior em relação ao grupo controle $(3010,5 \pm 182,7$ vs. $2053,7 \pm 168,2 \mathrm{mmHg} / \mathrm{s}$ no grupo controle) e também significativamente superior em relação ao grupo PD (3010,5 $\pm 182,7$ vs. $1958,6 \pm 37 \mathrm{mmHg} / \mathrm{s}$ no grupo PD).

Durante a reperfusão, onde diversos mecanismos intracelulares são deflagrados na tentativa de adequar o coração à sua nova situação de perfusão, o comportamento dos corações submetidos ao tratamento com T3 foi mantido similar àquele encontrado no período de estabilização, ou seja, houve um significativo aumento da $+\mathrm{dP} / \mathrm{dt}$ nos três períodos avaliados. Aos 25 minutos de reperfusão, este parâmetro mostrou-se $44 \%$ acima do observado nos animais do grupo controle $(2556,1 \pm 178,7$ vs. $1770 \pm 146,1 \mathrm{mmHg} / \mathrm{s}$ no grupo controle), $27 \%$ aos 35 minutos (2786,7 $\pm 168,8$ vs. $1997,4 \pm 151,2$ $\mathrm{mmHg} / \mathrm{s}$ no grupo controle), e $69 \%$ aos 45 minutos de reperfusão $(2911,1 \pm$ 59,9 vs. $1726,4 \pm 89,2 \mathrm{mmHg} / \mathrm{s}$ no grupo controle).

O bloqueio do receptor AT2 foi capaz de prefenir o efeito do T3 no aumento $\mathrm{da}+\mathrm{dP} / \mathrm{dt}$ em todos os tempos de reperfusão. Aos 25 minutos de reperfusão este parâmetro no grupo PD+T3 foi cerca de 30\% inferior ao grupo hipertiroideo (1673,4 $\pm 182,7$ vs. $2556,1 \pm 178,7 \mathrm{mmHg} / \mathrm{s}$ no grupo T3), o mesmo ocorrendo aos 35 minutos (1917,5 $\pm 107,7$ vs. $2786,7 \pm 168,8 \mathrm{mmHg} / \mathrm{s}$ no grupo T3), e aos $45 \mathrm{~min}$. de reperfusão (2078,6 $\pm 91,7$ vs. $2911,1 \pm 59,9$ $\mathrm{mmHg} / \mathrm{s}$ do grupo T3). 
Figura 7 - Primeira derivada positiva $(+\mathrm{dP} / \mathrm{dt})$

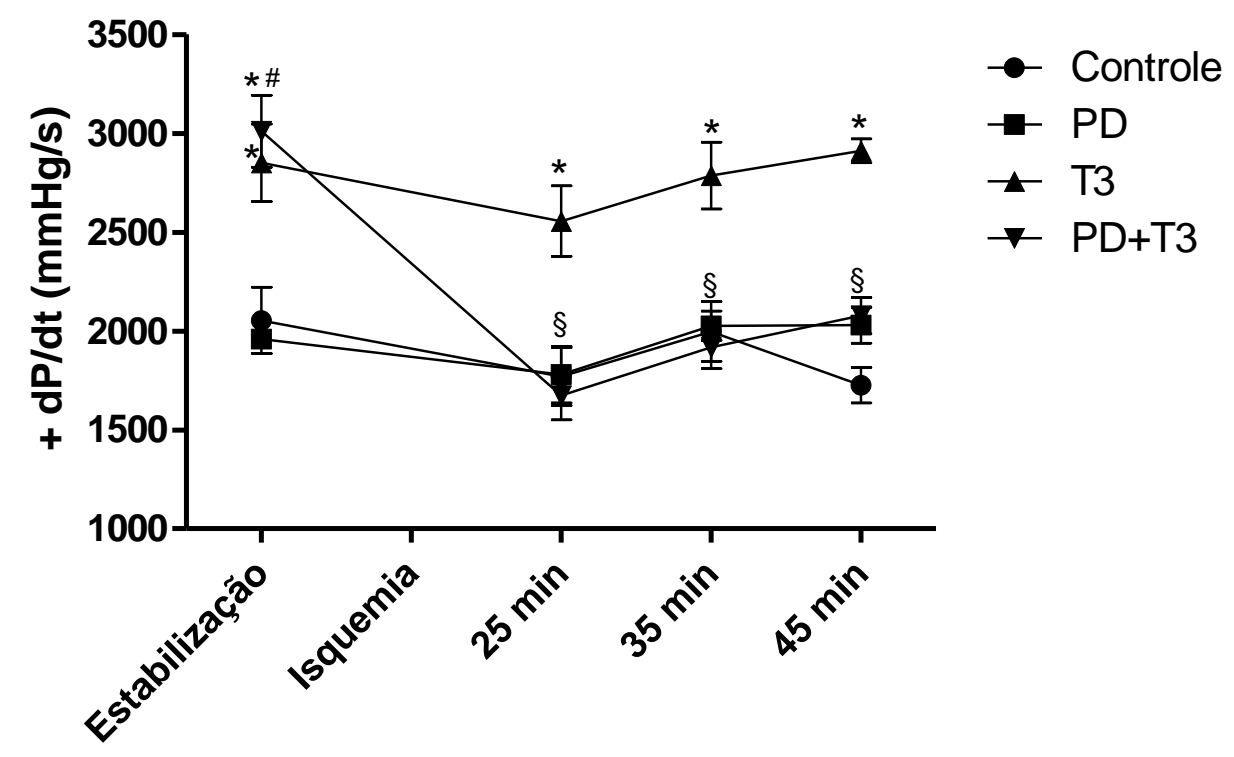

$+\mathrm{dP} / \mathrm{dt}$ avaliada nos períodos de Estabilização, 25 min de reperfusão, $35 \mathrm{~min}$ de reperfusão e 45 min de reperfusão (controle $n=9 ; P D n=8 ; T 3 n=7 ; P D+T 3 n=7$ ). * vs. controle $(p<0,05)$, \# vs. PD $(p<0,05)$, § vs. T3 $(p<0,05)$.

Fonte: Tavares (2012).

\subsubsection{Primeira Derivada Negativa (-dP/dt)}

Como dito anteriormente a $\mathrm{dP} / \mathrm{dt}$, representação da taxa de variação de pressão no tempo, consiste na primeira derivada temporal da pressão ventricular, que pode ser positiva $(+d P / d t)$ ou negativa $(-d P / d t)$. A $-d P / d t$ também é um índice utilizado para avaliação da função do ventrículo esquerdo. Com este parâmetro é possível avaliar indiretamente a capacidade de relaxamento global do coração, que diz respeito a outra propriedade do coração, o lusitropismo. O lusitropismo está relacionado com o relaxamento do músculo cardíaco, que dependente de gasto energético e de ações iônicas e enzimáticas específicas. É o fenômeno de relaxamento diastólico determinado pelo fim do processo de contração, quando termina a estimulação elétrica.

Conforme podemos observar na Figura 8, no período de estabilização os corações do grupo T3 apresentaram redução significativa (37\%) neste parâmetro, em relação aos do grupo controle $(-1425,5 \pm 116,1$ vs. $-1036,7 \pm$ $100,7 \mathrm{mmHg} / \mathrm{s}$ no grupo controle). Entretanto, aos 25 minutos de reperfusão 
essa diferença desapareceu, não havendo alteração deste parâmetro entre os grupos experimentais.

Enquanto os corações se estabilizam novamente na condição pósisquemia, as diferenças entre os grupos experimentais relacionados à $-\mathrm{dP} / \mathrm{dt}$ começam a se evidenciar aos 35 minutos de reperfusão, onde os corações dos animais do grupo T3 apresentaram redução significativa (40\%) deste parâmetro (-1647,3 \pm 31 vs. $-1172,9 \pm 125,6 \mathrm{mmHg} / \mathrm{s}$ no grupo controle). Vale ressaltar que aos 45 minutos de reperfusão houve uma redução ainda maior deste parâmetro nos corações hipertiroideos, sendo $70 \%$ maior que o observado no grupo controle (-1819,6 \pm 27 vs. $-1071,7 \pm 63,3 \mathrm{mmHg} / \mathrm{s}$ no grupo controle).

$\mathrm{O}$ tratamento dos animais com o bloqueador do receptor AT2 promoveu uma tendência de redução da $-\mathrm{dP} / \mathrm{dt}$ após $35 \mathrm{~min}$ de reperfusão, a qual se mostrou significativamente aumentada (44\%) aos 45 minutos de reperfusão (-1456,1 $\pm 139,1$ vs. $-1172,9 \pm 125,6 \mathrm{mmHg} / \mathrm{s}$ do grupo controle). O bloqueio do receptor AT2 (grupo PD+T3) preveniu a redução da -dP/dt induzida pelo T3 aos 35 minutos de reperfusão em $36 \%(-1057,9 \pm 43,1$ vs. $-1647,3 \pm 31 \mathrm{mmHg} / \mathrm{s}$ do grupo T3) e aos 45 minutos de reperfusão em $51 \%$ ( $-876,8 \pm 30,6$ vs. $-1819,6 \pm$ $27 \mathrm{mmHg} / \mathrm{s}$ do grupo T3).

$O$ efeito do tratamento concomitante dos dois fármacos foi também capaz de prevenir a redução deste parâmetro observado no grupo PD em 37\% aos 35 minutos de reperfusão $(-1057,9 \pm 43,1$ vs. $-1456,1 \pm 139,1 \mathrm{mmHg} / \mathrm{s}$ do grupo PD) e $43 \%$ aos 45 minutos de reperfusão (-876,8 $\pm 30,6$ vs. $-1545 \pm 29,3$ $\mathrm{mmHg} / \mathrm{s}$ do grupo PD). 
Figura 8 - Primeira derivada negativa $(-\mathrm{dP} / \mathrm{dt})$

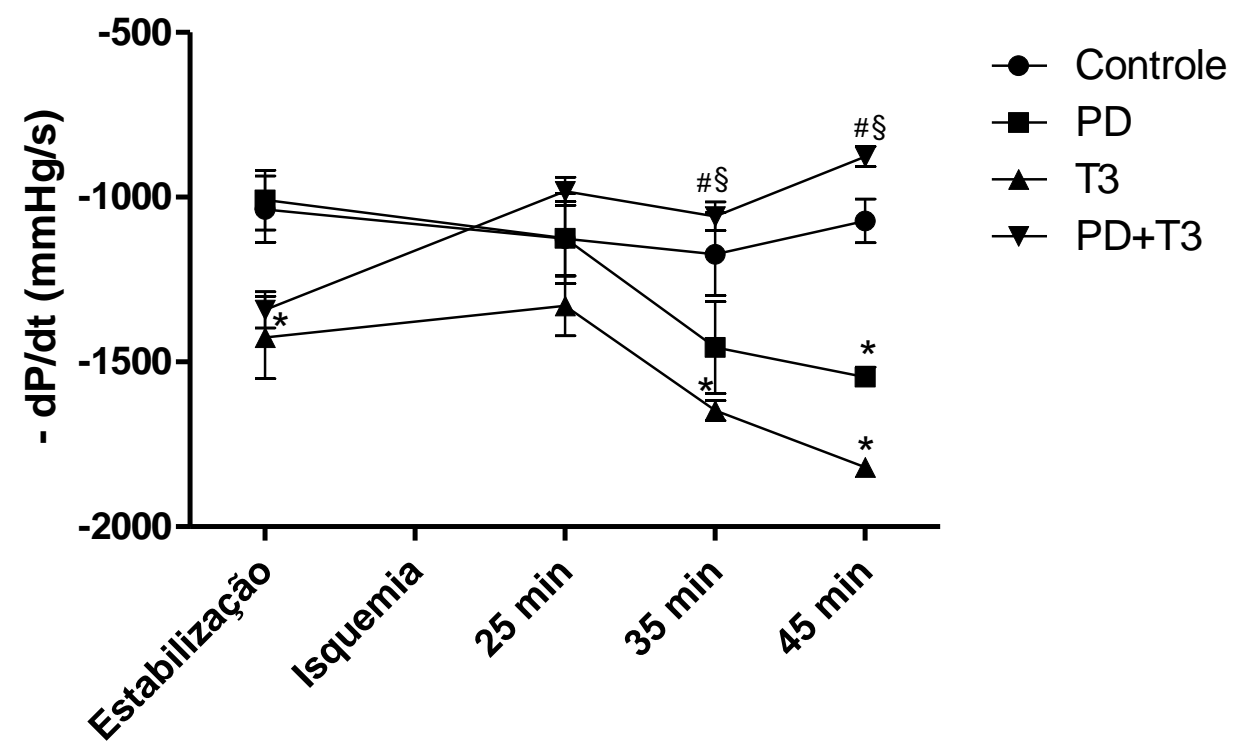

-dP/dt avaliada nos períodos de Estabilização, 25 min de reperfusão, 35 min de reperfusão e 45 min de reperfusão (controle $n=9$; PD $n=8 ; T 3 n=7 ; P D+T 3 n=7$ ). * vs. controle $(p<0,05)$, \# vs. PD ( $p<0,05)$, $\S$ vs. T3 $(p<0,05)$.

Fonte: Tavares (2012).

\subsubsection{Frequência Cardíaca}

Outra propriedade cardíaca avaliada neste estudo foi o cronotropismo. Esta propriedade é fundamental para a função cardíaca e demonstra a capacidade do coração em gerar seus próprios impulsos elétricos, independentemente de influências extrínsecas ao órgão. Fatores como íons plasmáticos, temperatura e irrigação coronariana exercem importante influência sobre o automatismo e o cronotropismo. Os estímulos responsáveis pela excitação automática do miocárdio podem iniciar em qualquer parte do coração. Certas regiões, no entanto, possuem a capacidade de gerar estímulos de forma particular, fazendo-o com uma freqüência própria e mais elevada que aquela das demais regiões cardíacas, devido à sua diferenciação morfofuncional e consequente peculiaridade eletrofisiológica. A região de automatismo que possui a freqüência de descarga mais rápida comanda a ativação elétrica cardíaca, submetendo a excitação de todo o coração ao seu próprio ritmo, pelo que é denominado de marca-passo do coração, representado pelo nodo sinusal. Na figura a seguir (Figura 9) são apresentados 
os valores de Frequência Cardíaca Intrínseca, ou sinusal, uma vez que o coração encontrava-se isolado dos demais órgãos e com a temperatura, fluxo de perfusão e solução de perfusão controlados, no intuito de manter este parâmetro independente de influências extrínsecas.

Conforme podemos observar a Frequência cardíaca (FC) intrínseca apresentou-se significativamente aumentada no período de estabilização nos corações de todos os grupos experimentais, em relação aos do grupo controle. A maior diferença deste parâmetro em relação ao grupo controle foi encontrada no grupo T3, com aumento de $38 \%$ (276 \pm 5 vs. $200 \pm 15$ bpm no grupo controle).

No período pós-isquêmico, os corações não apresentaram mais diferença estatisticamente significativa entre os grupos experimentais, aos $25 \mathrm{e}$ 35 minutos de reperfusão do tecido cardíaco. Somente após 45 minutos de reperfusão a FC mostrou-se alterada entre os diferentes grupos experimentais. Assim, observou-se significativa redução da FC no grupo PD em relação ao grupo controle em 14\% (208 \pm 6 vs. $242 \pm 11$ bpm do grupo controle). O grupo tratado com T3 apresentou um aumento significativo deste parâmetro em 20\% (291 \pm 5 vs. $242 \pm 11$ bpm do grupo controle), no entanto este efeito foi totalmente prevenido no grupo que recebeu concomitantemente o bloqueador do receptor $\mathrm{AT} 2$ (grupo $\mathrm{PD}+\mathrm{T} 3$ ), voltando a $\mathrm{FC}$ para valores similares àqueles do grupo controle. 
Figura 9 - Frequência Cardíaca (FC)

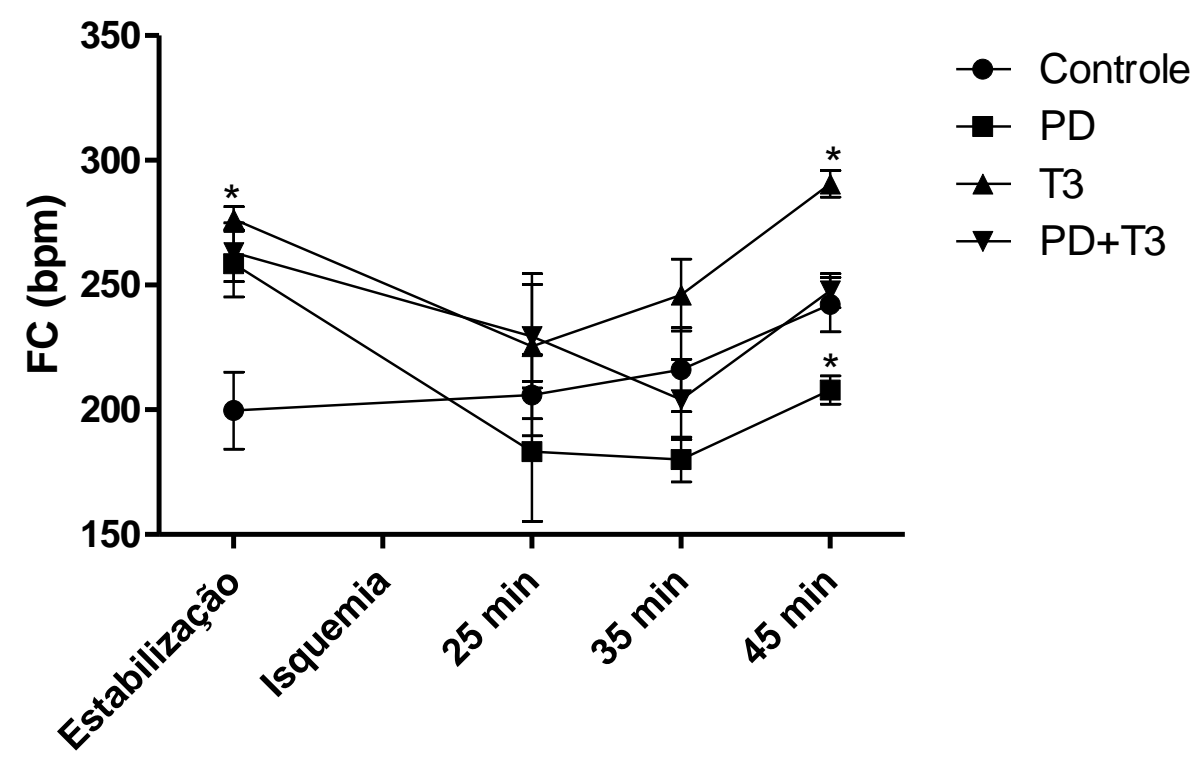

FC avaliada nos períodos de Estabilização, $25 \min$ de reperfusão, 35 min de reperfusão e 45 min de reperfusão (controle $n=9$; PD $n=8$; T3 $n=7 ; P D+T 3 n=7$ ). * vs. controle $(p<0,05)$, $\S$ vs. T3( $p<0,05)$.

Fonte: Tavares (2012).

\subsubsection{Pressão de Perfusão}

A pressão de perfusão e o fluxo coronário se ajustam dinamicamente às necessidades metabólicas do miocárdio. Essa regulação é propiciada por mecanismos adaptativos envolvendo a taxa de metabolismo, o reflexo miogênico e a participação de fatores endoteliais, dentre outros. A pressão de perfusão é o resultado da pressão exercida pelas coronárias ao receber um fluxo constante, neste caso de $8-10 \mathrm{ml} / \mathrm{min}$. Este parâmetro torna possível avaliar indiretamente o estado de relaxamento e constrição das artérias coronárias sob diferentes condições experimentais e em diferentes tempos de reperfusão tecidual.

A pressão de perfusão foi o único parâmetro que não variou entre os diferentes grupos experimentais nos períodos de reperfusão do tecido cardíaco (Figura 10). Entretanto, vale ressaltar que durante o período de estabilização os corações dos grupos que receberam o tratamento com Hormônio Tiroideano (T3 e PD+T3), apresentaram uma pressão de perfusão significativamente 
inferior àquela dos corações do grupo controle $(55,4 \pm 3,4$ e 53,5 $\pm 2,3$, respectivamente, vs. $77,1 \pm 4,4 \mathrm{mmHg}$ no grupo controle).

Figura 10 - Pressão de Perfusão

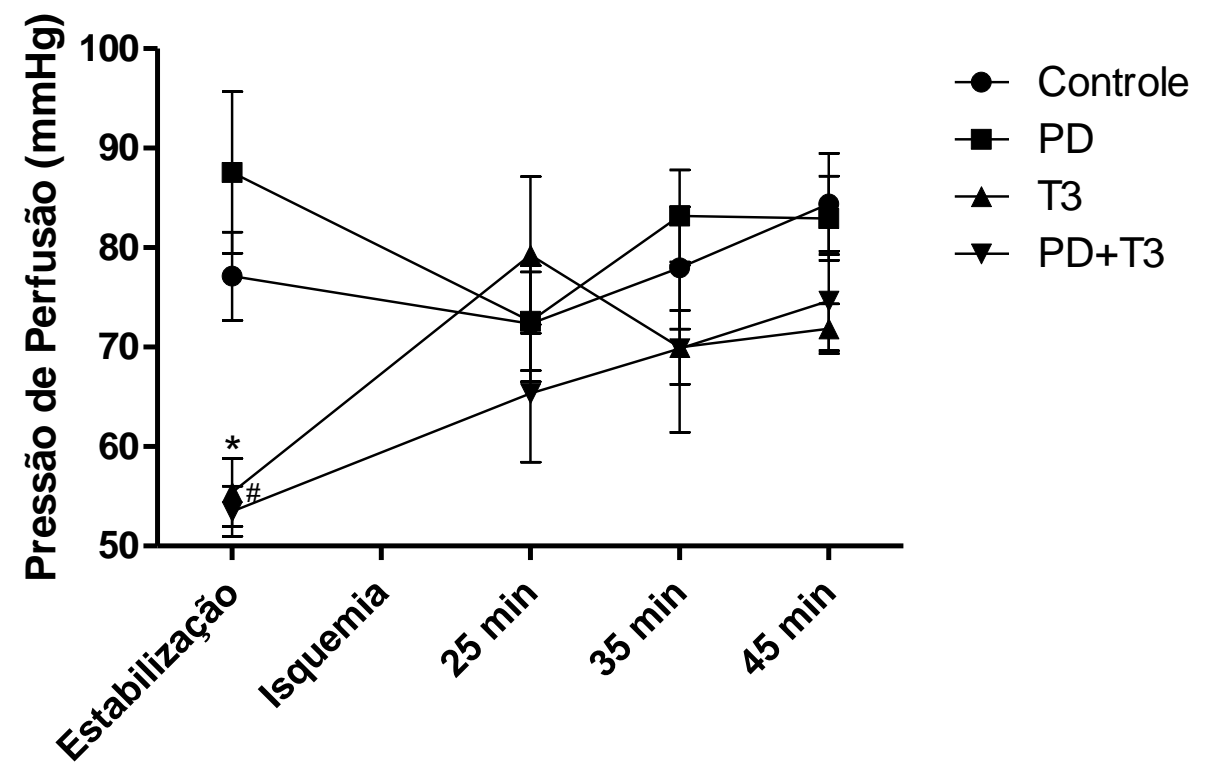

Pressão de Perfusão avaliada nos períodos de: Estabilização, 25 min de reperfusão, 35 min de reperfusão e 45 min de reperfusão. (controle $n=9 ; P D ~ n=8 ; T 3 n=7 ; P D+T 3$ $n=7) .{ }^{*}$ vs. controle $(p<0,05)$, \# vs. PD $(p<0,05)$.

Fonte: Tavares (2012).

\subsection{Efeito do bloqueio do Receptor AT2 na recuperação da função} cardíaca, em animais hipertiroideos, frente a situações de I/R

Foi visto até agora como os corações dos animais dos diferentes grupos experimentais se comportaram frente a períodos distintos de reperfusão do tecido cardíaco, e também antes mesmo do período de isquemia (período de estabilização). No entanto esses dados não nos permitem ter uma ideia clara do grau de recuperação cardíaca que os diferentes grupos apresentaram. Neste contexto, decidimos analisar essa recuperação como a porcentagem de alteração dos diferentes parâmetros avaliados durante o período de reperfusão, considerando o período de estabilização de cada coração como controle. Desta forma, os valores de $100 \%$ nas figuras apresentadas a seguir irão corresponder e representar o retorno daquele determinado parâmetro de função cardíaca às 
condições iniciais, observadas no período de estabilização (Figuras 11, 12 e 13).

\subsubsection{Reperfusão (25 minutos)}

Após 25 minutos de reperfusão pode ser observado que os corações dos animais do grupo que recebeu o tratamento concomitante de PD e T3 apresentaram certo comprometimento de alguns parâmetros da função cardíaca. Assim, os animais desse grupo tiveram uma recuperação parcial da LVDP (de 65\%). Os animais submetidos ao hipertiroidismo (grupo T3) mostraram valores similares àqueles observados no período de estabilização, recuperando, portanto, a LVDP (Figura 11A). O mesmo foi observado em relação ao parâmetro de $+\mathrm{dP} / \mathrm{dt}$, onde o grupo PD+T3 apresentou apenas 53\% de recuperação, significativamente inferior ao grupo controle (Figura 11B) 
Figura 11 - Porcentagem de alteração dos parâmetros avaliados aos 25 minutos de reperfusão.

(A)

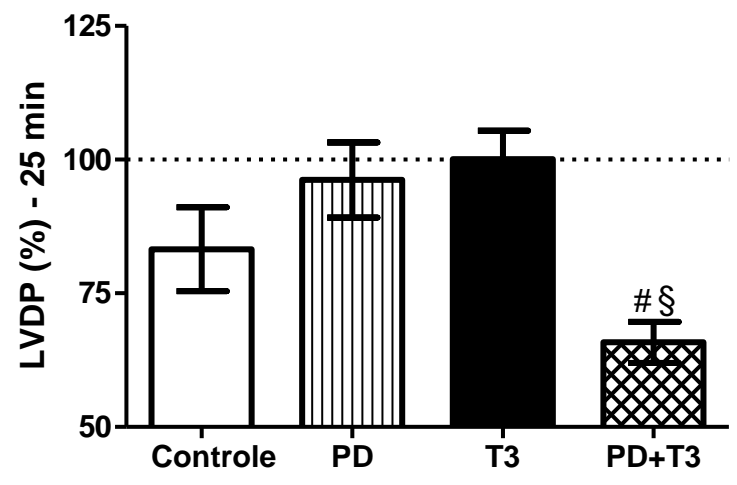

(C)

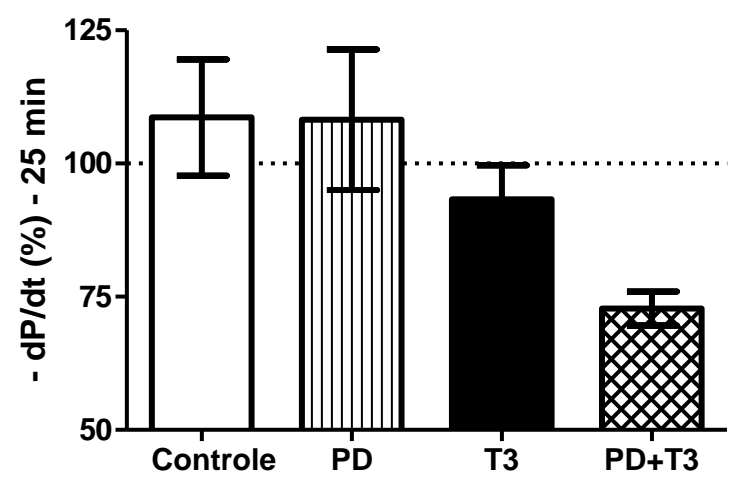

(B)

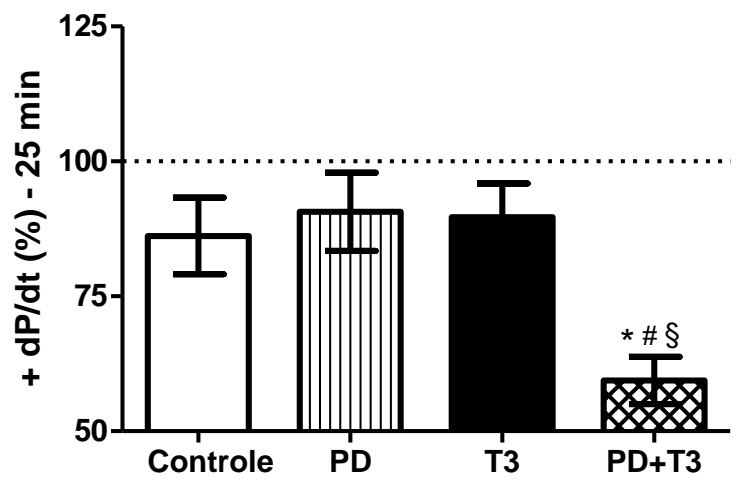

(D)

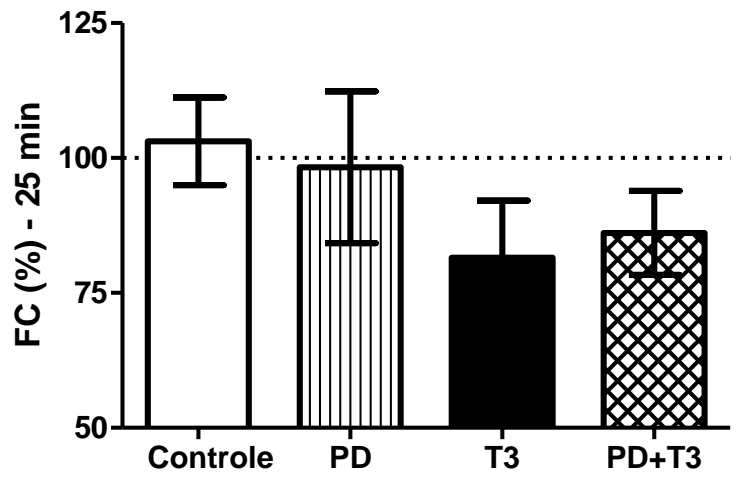

(A) LVDP, (B) $+\mathrm{dP} / \mathrm{dt}$, (C) -dP/dt e (D) Frequência Cardíaca aos 25 minutos de reperfusão. (controle $n=9 ; P D n=8 ; T 3 n=7 ; P D+T 3 n=7)$. * vs. controle $(p<0,05)$, \# vs. PD ( $p<0,05), \S$ vs. T3 $(p<0,05)$.

Fonte: Tavares (2012).

\subsubsection{Reperfusão (35 minutos).}

Durante os 35 minutos de reperfusão os corações do grupo T3 não só mostraram recuperação da LVDP, como obtiveram valores 10\% superiores àqueles encontrados na estabilização (Figura 12A). Já o grupo PD+T3 apresentou uma recuperação parcial desse parâmetro, cerca de $72 \%$. Novamente, no que se refere aos parâmetros de $+\mathrm{dP} / \mathrm{dt}$ e $-\mathrm{dP} / \mathrm{dt}$ o grupo PD+T3 apresentou uma recuperação apenas parcial (de 68\% e 77\%, respectivamente), enquanto os demais grupos experimentais voltaram a 
apresentar comportamento próximo às condições de estabilização (Figura 12 $B, C)$.

Figura 12 - Porcentagem de alteração dos parâmetros avaliado aos 35 minutos de reperfusão.

(A)

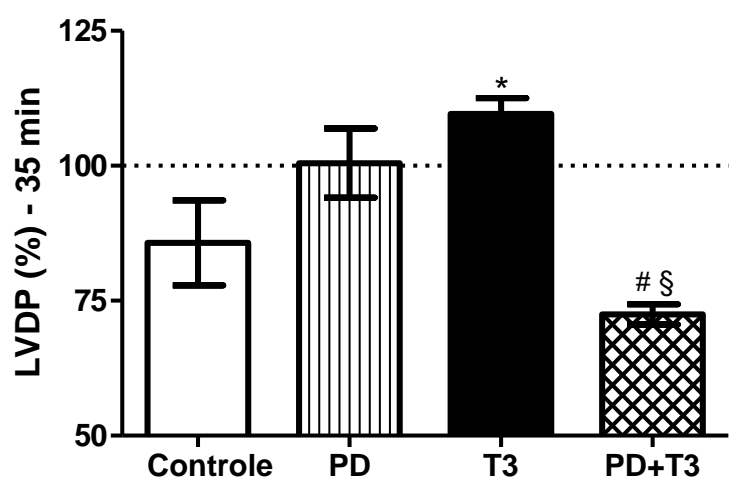

(C)

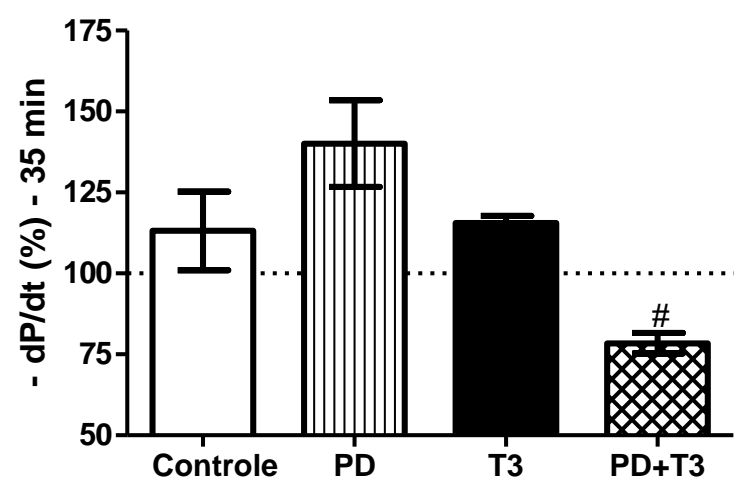

(B)

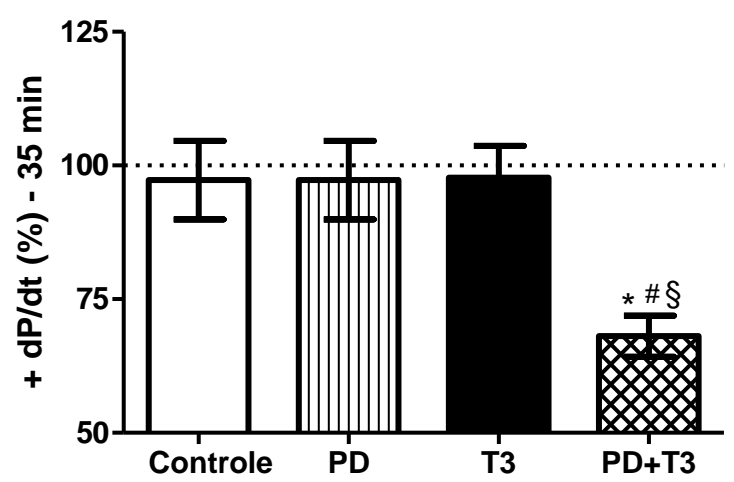

(D)

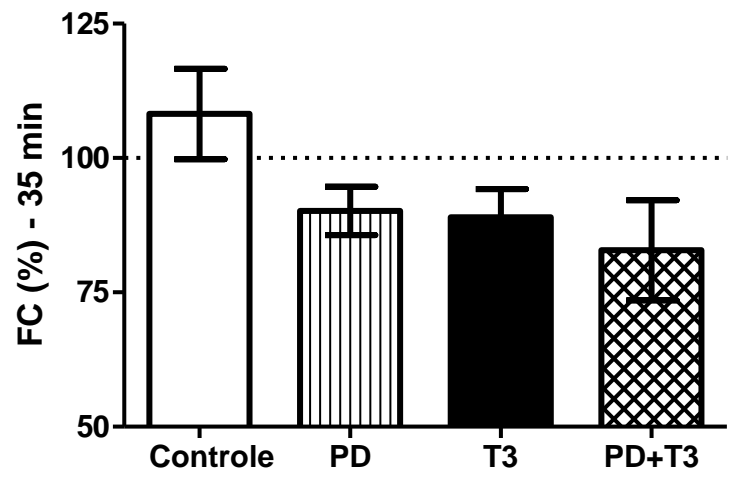

(A) LVDP, (B) +dP/dt, (C) -dP/dt e (D) Frequência Cardíaca aos 35 minutos de reperfusão (controle $n=9 ; P D n=8 ; T 3 n=7 ; P D+T 3 n=7)$. * vs. controle $(p<0,05)$, \# vs. PD $(p<0,05), \S$ vs. T3( $p<0,05)$.

Fonte: Tavares (2012).

\subsubsection{Reperfusão (45 minutos).}

No último período avaliado, aos 45 minutos de reperfusão, somente a FC não teve diferenças na recuperação após a isquemia, perfil encontrado também nos tempos avaliados anteriormente, 25 e 35 minutos (Figura 13D). Com relação à LVDP, os corações do grupo PD+T3 mostraram recuperação de 
apenas $73 \%$, sendo que os demais grupos tiveram valores de LVDP ainda ligeiramente superiores àqueles encontrados na estabilização (Figura 13A). 0 mesmo foi encontrado no que se refere aos parâmetros de $+\mathrm{dP} / \mathrm{dt}$ e $-\mathrm{dP} / \mathrm{dt}$ os quais o grupo PD+T3 apresentou apenas recuperação parcial (74\% e 77\%, respectivamente) (Figura 13B,C). Vale ressaltar que os grupos PD e T3 tiveram valores percentuais de $-\mathrm{dP} / \mathrm{dt}$ bastante superiores àqueles observados no período de estabilização.

Figura 13 - Porcentagem de alteração dos parâmetros avaliados aos 45 mintutos de reperfusão.

(A)

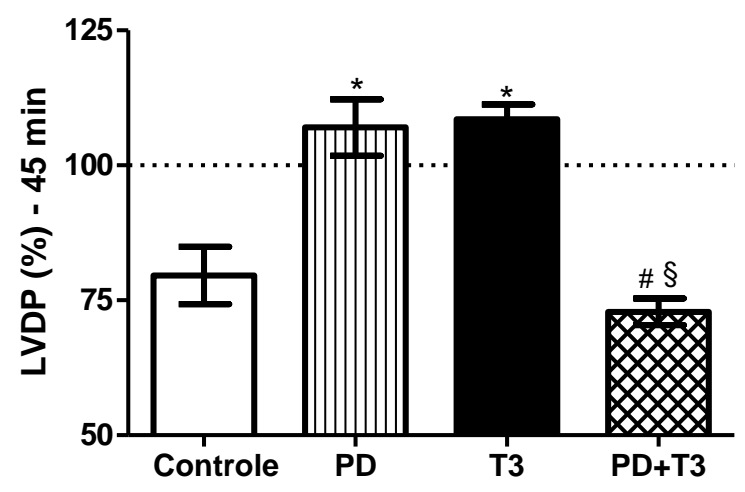

(C)

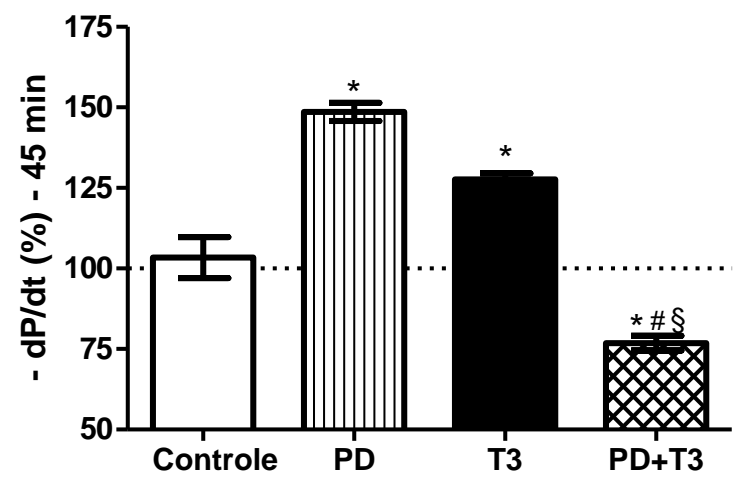

(B)

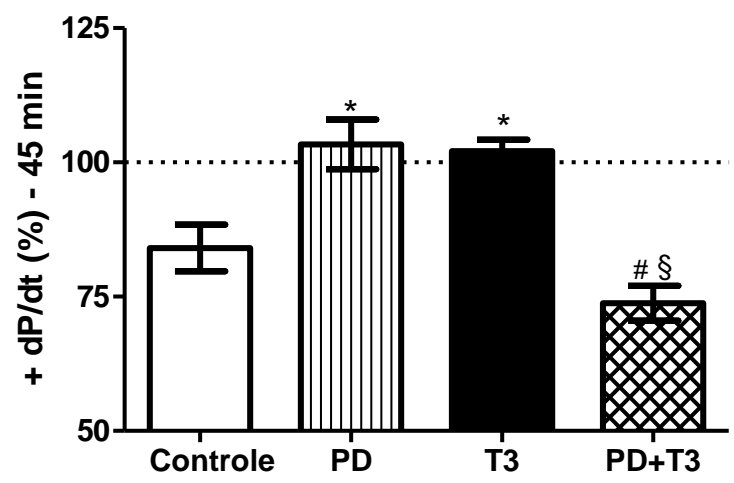

(D)

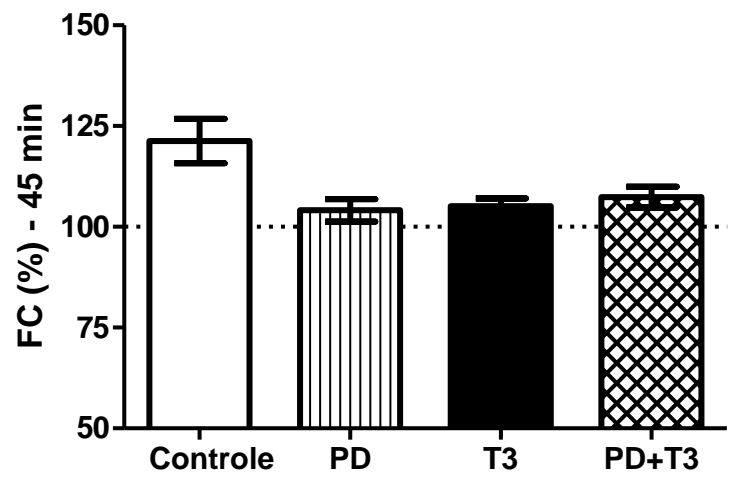

(A) LVDP, (B) $+d P / d t$, (C) -dP/dt e (D) Frequência Cardíaca aos 45 minutos de reperfusão. (controle $n=9 ; P D n=8 ; T 3 n=7 ; P D+T 3 n=7)$. * vs. controle $(p<0,05)$, \# vs. PD $(p<0,05)$, § vs. T3 $(p<0,05)$.

Fonte: Tavares (2012). 


\subsection{Análise dos níveis de Angiotensina I e II e da expressão dos receptores de Angiotensina II (AT1 e AT2)}

Os resultados apresentados até 0 momento referem-se àqueles relacionados a parâmetros de função cardíaca, obtidos junto aos experimentos de I/R de corações isolados, usando o método de perfusão de Langendorff. Posteriormente a estes experimentos, foi realizada a técnica de Westen Blotting para averiguar os níveis de Angl/Angll e a expressão protéica dos receptores AT1 e AT2 nos diferentes grupos experimentais.

A técnica imunodetecção foi o método indireto, utilizado neste estudo, para medir os níveis de Ang II, peptídeo responsável por inúmeras ações do SRA. Os resultados revelaram que não houve diferença estatística significante dos níveis de Ang I/II entre o grupo T3 e o grupo que recebeu o tratamento combinado de PD e T3, sendo encontrado neste último um aumento estatisticamente significante em relação ao grupo controle e PD. No entanto nenhuma diferença estatística significante foi encontrada entre os demais grupos experimentais. (Figura 14)

Em relação à expressão do receptor AT1, receptor dominante do tecido cardíacao adulto e responsável pela maioria das ações fisiológicas da Ang II (Matsubara et al., 1994), não foram encontradas diferenças significativas entre os diferentes grupos experimentais, tanto no que se refere ao subtipo AT1a como AT1b, isoformas do receptot AT1 encontradas somente em roedores (Figura 15).

Já no que diz respeito ao receptor AT2, receptores que são reexpressos e regulados positivamente na hipertrofia cardíaca, infarto do miocárdio e na insuficiência cardíaca (Horiuchi et al.,1999), os resultados deste estudo mostram um aumento de $36 \%$ na sua expressão no grupo T3, quando comparado à situação controle (Figura 16). Observou-se também que o efeito do bloqueio do receptor AT2, quando associado ao tratamento de hipertiroidismo, foi capaz de prevenir o aumento da expressão deste receptor, pois não houve diferença significativa entre este grupo e a situação controle, como observado no grupo T3. 
Figura 14 - Análise dos níveis de Angiotensina I/II.
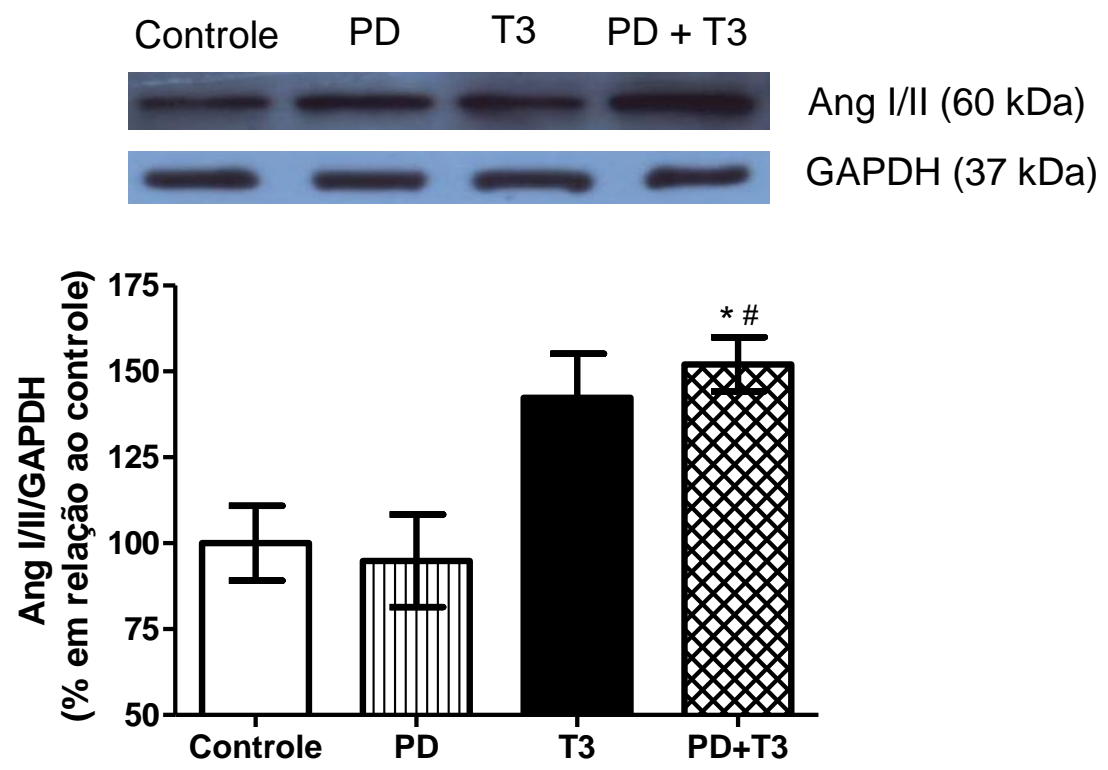

Análise dos níveis de Angiotensina I/II. Os valores são descritos em percentual de variação em relação ao grupo controle (controle $n=4 ; P D n=4 ; T 3 n=4 ; P D+T 3 n=4$ ). * vs controle $(p<0,05)$, \# vs PD $(p<0,05)$.

Fonte: Tavares (2012).

Figura 15 - Análise da expressão protéica do receptor AT1a e AT1b.
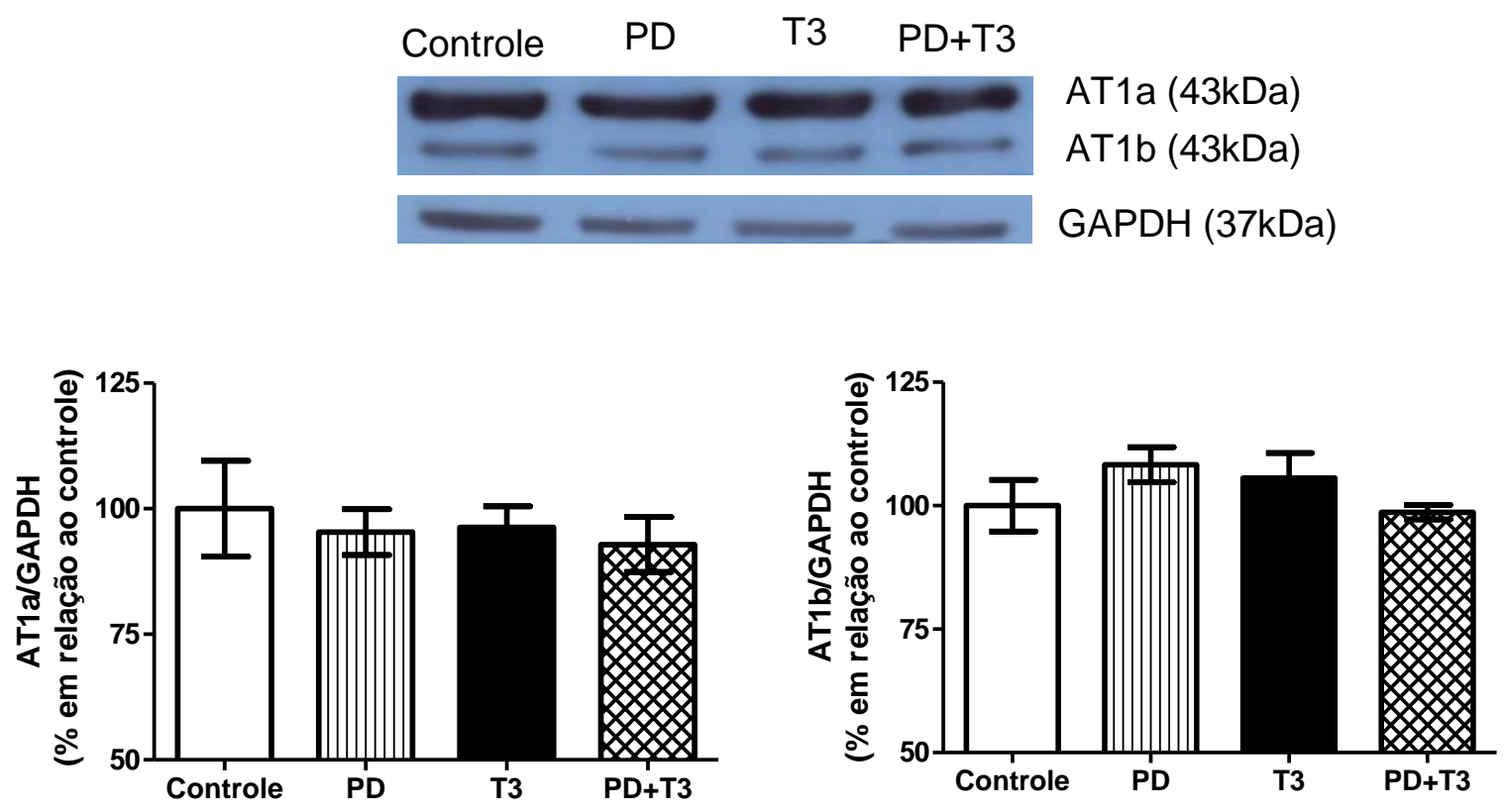

Análise da expressão protéica do receptor AT1a e AT1b. Os valores são descritos em percentual de variação em relação ao grupo controle (controle $n=4$; PD $n=4 ;$ T3 $n=4$; $\mathrm{PD}+\mathrm{T} 3 \mathrm{n}=4)$.

Fonte: Tavares (2012). 
Figura 16 - Análise da expressão protéica do receptor AT2.
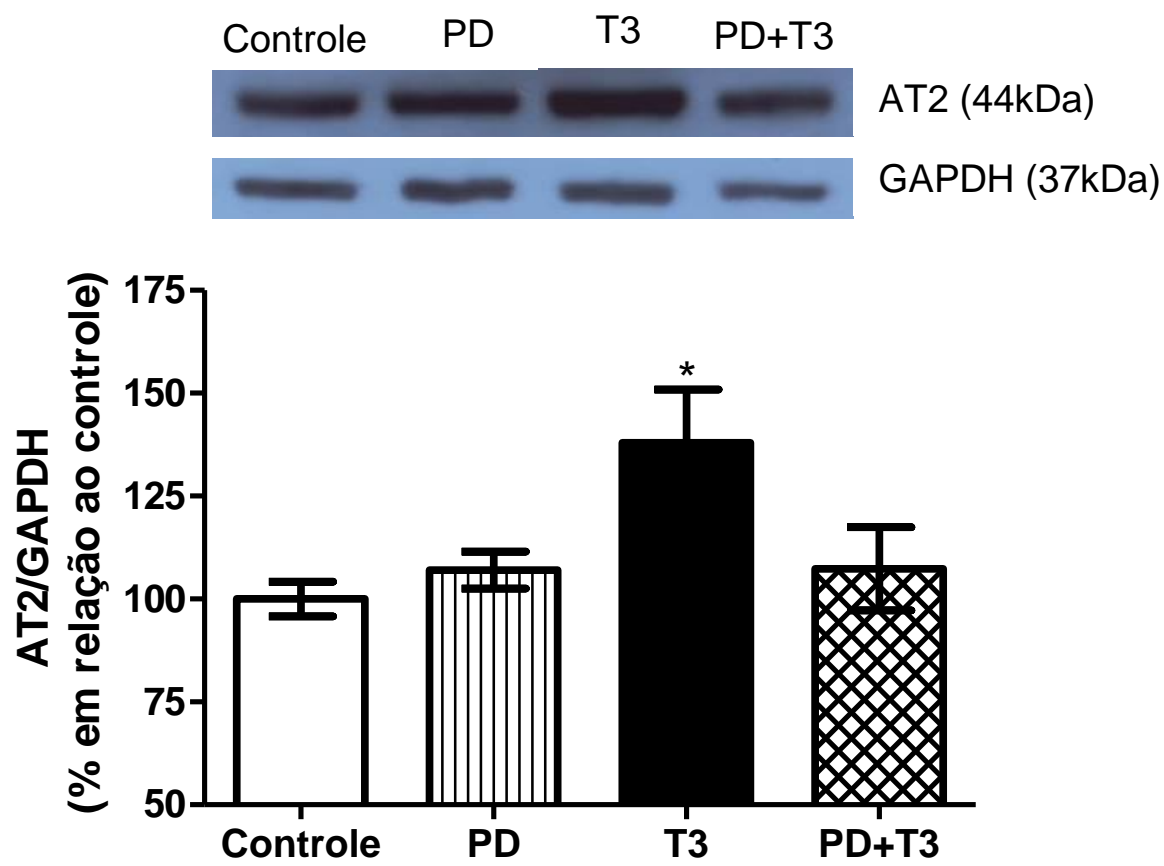

Análise da expressão protéica do receptor AT2. Os valores são descritos em percentual de variação em relação ao grupo controle (controle $n=4$; PD $n=4 ; T 3 n=4$; $P D+T 3 n=4)$. * vs controle $(p<0,05)$.

\subsection{Efeito da Isquemia e Reperfusão no estado de fosforilação da AMPK nos diferentes grupos experimentais}

À expressão protéica da AMPK, proteína que desempenha papel fundamental do metabolismo cardíaco e atua em situações de estresse como de $\mathrm{I} / \mathrm{R}$, pomovendo aumento do suprimento energético durante a isquemia e aumento da captação de glicose durante a reperfusão (Morrisson, 2011), foi avaliada e os resultados deste estudo mostraram que aumento estatísticamente significativo da sua fração fosforilada (em torno de $70 \%$ ), no grupo T3 em relação ao grupo controle. Foi observado também que o efeito do bloqueio do receptor AT2 foi tão intenso que o grupo que recebeu o tratamento combinado ( $P D+T 3$ ) apresentou valores da expressão fosforilada da AMPK significativamente menores em relação ao grupo T3 (Figura 16). Com relação à fração total dessa proteína, não foram identificadas diferenças significativas entre os grupos (Figura 17). 
Figura 17 - Análise da expressão protéica da AMPK

(A)

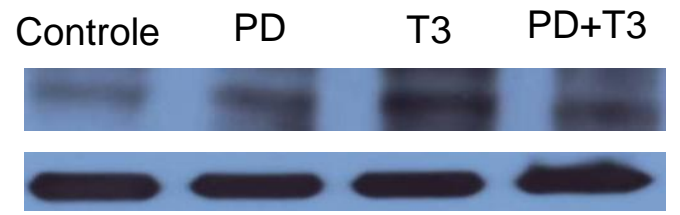

p- $\operatorname{AMPK\alpha }\left(\operatorname{Tre}^{172}\right)$

(63kDa)

GAPDH $(37 \mathrm{kDa})$

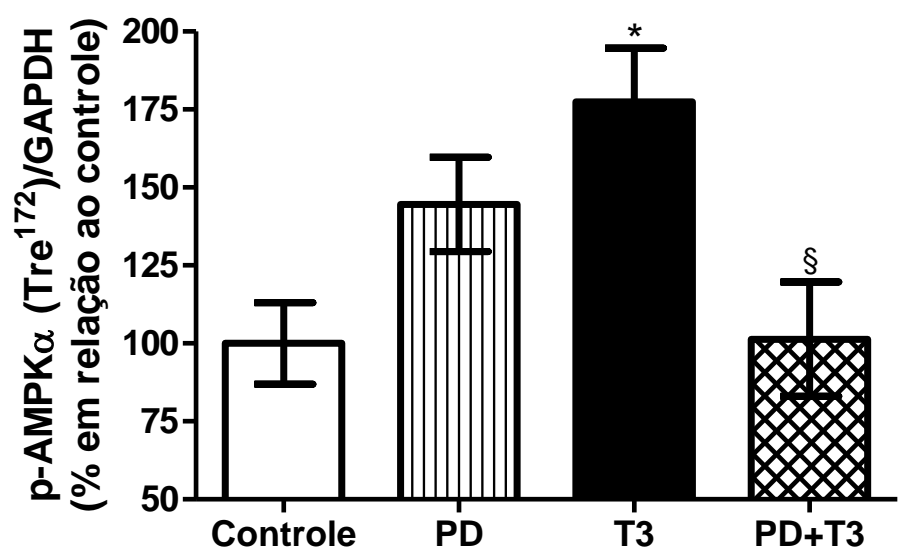

(B)
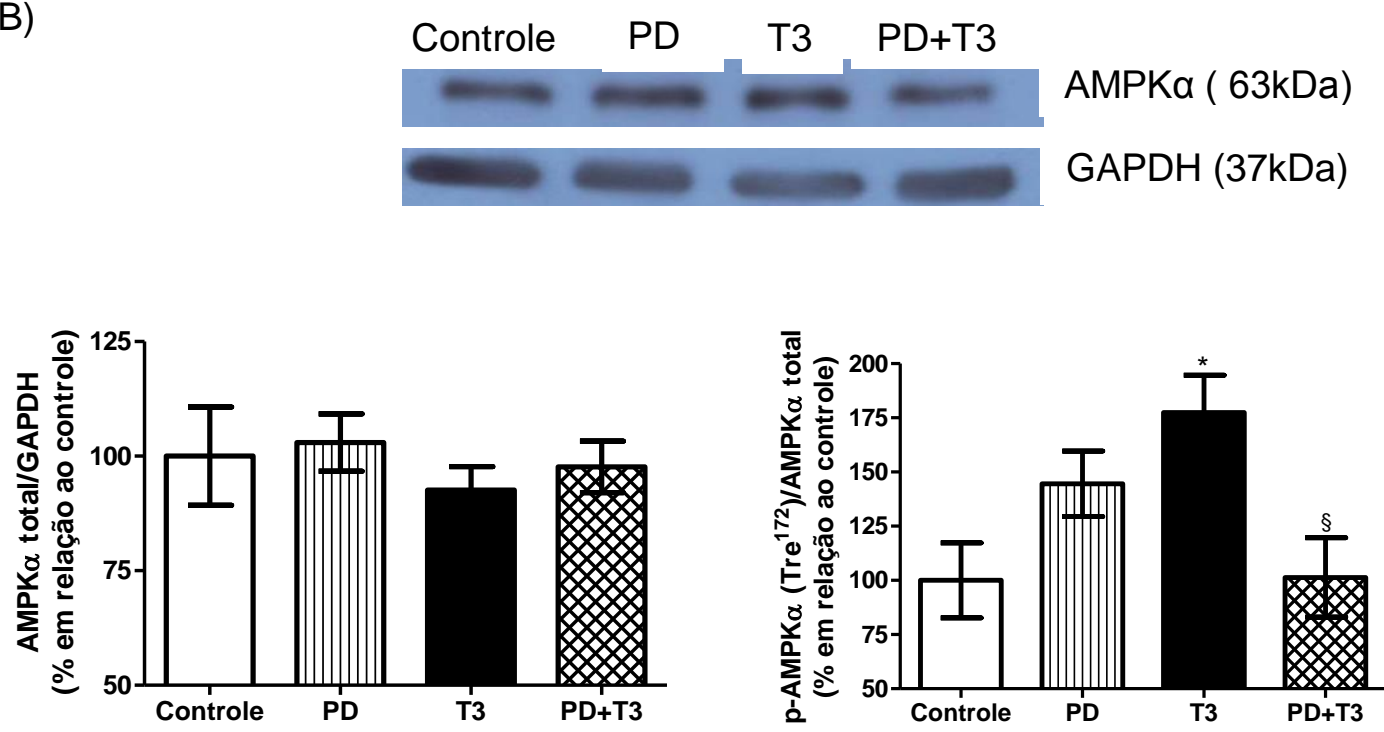

Análise da expressão protéica da AMPK. (A) Análise dos níveis de AMPKa fosforilada na $\operatorname{Ter}^{172}$ (B) AMPKa total e razão da AMPKa fosforilada na $\operatorname{Ter}^{172} /$ AMPKa total após a injúria de $\mathrm{I} / \mathrm{R}$ nos diferentes grupos experimentais. Os valores são descritos em percentual de variação em relação ao grupo controle (controle $n=4$; PD $n=4$; T3 $n=4$; $P D+T 3 n=4) .{ }^{*}$ vs controle $(p<0,05), \S$ vs. T3 $(p<0,05)$. 


\section{DISCUSSÃO}

O presente estudo teve como objetivo avaliar a participação do receptor AT2 na resposta cardioprotetora induzida pelo Hormônio Tiroideano no modelo de Isquemia-Reperfusão (l/R), em corações isolados de ratos, bem como a contribuição da via de sinalização AMPK em resposta ao estresse isquêmico.

Para responder tais objetivos, o passo inicial foi avaliar a cardioproteção induzida pelo HT no modelo utilizado neste estudo. $O$ modelo de hipertiroidismo utilizado foi confirmado através da mensuração da hipertrofia cardíaca, e das dosagem séricas dos HT. Os resultados deste estudo mostraram um evidente aumento da massa muscular cardíaca nos grupos tratados com HT, sendo que o grupo tratado somente com T3 apresentou aumento significativo da concentração de T3 na circulação em relação ao grupo controle, ao mesmo tempo, a redução do T4 chegou a níveis insignificantes, como mecanismo de feedback entre esses hormônios, uma vez que a maior parte do T3 circulante é resultante da ação de enzimas, chamadas desiodades, sobre o T4 (Nunes, 2003), sendo estas, portanto, enzimas críticas para os efeitos biológicos mediados pelos HTs.

Após confirmação do modelo experimental o efeito protetor do Hormônio Tiroideano no coração foi testado depois do pré-tratamento por 14 dias com T3. Este efeito protetor foi observado pelo aumento significativo dos parâmetros de LVDP, +dP/dt, -dP/dt, FC, além da diminuição da pressão de perfusão nos corações hipertiroideos, em relação aos corações controle. Pelo menos em parte, esse efeito protetor poderia ser explicado pelas várias ações que os HT apresentam sobre o metabolismo, uma vez que várias alterações bioquímicas são evidentes nos corações de ratos submetidos ao hipertireoidismo experimental durante a isquemia. Inicialmente uma diminuição do ATP, uma redução da produção de lactato e, em menor medida, uma diminuição no $\mathrm{pH}$ ocorrem em todos os corações hipertiroideos durante a isquemia (Buser et al., 1990; Bak et al., 2003) e isto pode ser atribuído à diminuição dos níveis de glicogênio do miocárdio que ocorrem após um pré-tratamento com T3 cronicamente (Van Der et al., 1998; Pantos el al., 2000).

Desta forma, os resultados deste estudo estão de acordo com trabalhos da literatura, uma vez que estudos anteriores já demonstraram, no modelo de 
coração isolado de rato, que a eficiência cardíaca aumenta após isquemia global e reperfusão de corações agudamente pré-tratados com T3 (Liu et al., 1998). Além disso, foi mostrado ainda que o pré-tratamento com T3 evita lesões de reoxigenação em outros tecidos (Erkan et al., 2003). Ainda no modelo de coração isolado, a melhora da função cardíaca foi também observada em estudos que se utilizaram do pré-tratamento crônico (por duas semanas) com T3, ocorrendo a melhora da recuperação pós isquêmica após isquemia com fluxo zero e reperfusão globais (Buser at al., 1990; Pantos et al., 2000; Venditti et al., 2000; Pantos et al., 2002; Pantos et al., 2003). Aliás, esses trabalhos da literatura, além dos dados prévios de nosso grupo foram os fatores que nos pautaram a escolher o modelo experimental utilizado no presente estudo.

A inter-relação entre a função cardíaca e o status metabólico indica que alterações no metabolismo podem ser determinantes importantes na resposta dos corações à isquemia. Logo após pré-tratamento de 2 dias com T3, não há diferença no conteúdo de glicogênio do miocárdio, contratura isquêmica ou recuperação da função pós-isquêmica entre os corações hipertiroideos e corações controle. No entanto, após pré-tratamento de 14 dias com T3, há declínio nos níveis de glicogênio, enquanto a contratura isquêmica é acelerada e a recuperação após a isquemia é aumentada (Van Der et al., 1998; Pantos et al., 2000). Nós não avaliamos neste estudo os níveis de glicogênio miocárdico, no entanto, a eficiência comprovada de nosso modelo de hipertiroidismo, bem como os parâmetros obtidos em nossos experimentos referentes à recuperação após isquemia nos fazem admitir que eles também encontrem-se diminuídos.

Ainda, a relação entre os níveis de glicogênio miocárdico, a contratura isquêmica e a recuperação da função pós-isquêmica também foi previamente demonstrada para o pré-condicionamento isquêmico. Assim, é interessante observar que a combinação destas duas intervenções, HT e précondicionamento, potencializam a recuperação pós-isquêmica (Kolocassides et al., 1996; Pantos et al., 1999). Com base nessas evidências, foi então proposto que a diminuição dos níveis de glicogênio no miocárdico antes da isquemia influencia na resposta funcional do coração hipertireoideo durante a injúria de 
I/R. Por um lado, o declínio da produção anaeróbia de ATP leva à exacerbação da contratura e, por outro lado, a produção de lactato diminui, o que ocasiona uma menor acidose e aumento da recuperação da função pós-isquêmica (Pantos et al., 1999; Pantos et al., 2000).

Um outro efeito benéfico dos hormônios tiroideanos sobre a função cardíaca pós-isquêmica foi também encontrado quando de sua administração foi realizada durante o período de reperfusão (Klemperer et al., 2002). Assim, a suplementação aguda de T3 durante a reperfusão apresentou melhora na recuperação contrátil de corações isolados de ratos submetidos ao estresse isquêmico (Dyket et al., 1991; Holland et al., 1992; . Kadletz et al., 1994). Além disso, em modelos animais de grande porte, a contratilidade ventricular esquerda após a isquemia melhorou significativamente após a administração de T3 (Novitzky et al., 1991; Dyke et al., 1993). Curiosamente, resultados semelhantes também foram relatados em pacientes submetidos à revascularização do miocárdio (Novitzky et al., 1989; Klemperer et al., 1995).

A administração de T3 no período pós-isquêmico pode influenciar até mesmo o remodelamento do ventrículo esquerdo. De fato, em um modelo experimental de infarto agudo do miocárdio em ratos, os níveis séricos de T3 caíram, o que foi associado com disfunção ventricular esquerda e alterações em vários genes responsivos ao $\mathrm{HT}$. O tratamento destes animais com doses elevadas de T3 resultou em melhora da função cardíaca com normalização da maioria das mudanças na expressão gênica (Ojamaa et al., 2000).

Em suma, com base nos resultados deste estudo, e naqueles observados na literatura, concluímos que os HT desempenham um papel regulatório da função contrátil do miocárdio na resposta do coração ao estresse isquêmico, sendo que o aumento de seus níveis séricos promovem efeitos benéficos na contratilidade e na resposta à isquemia. Além dos aspectos puramente metabólicos deflagrados pelo excesso dos $\mathrm{HT}$, o hipertireoidismo se caracteriza ainda por promover aumento da expressão de proteínas contráteis, indução de angiogênese, prevenção de fibrose e, de grande relevância, vasodilatação (Pantos et al., 2004). Certamente, essas ações, aliadas aos aspectos metabólicos já discutidos previamente, são também importantes, ou até mesmo determinantes, para os efeitos cardioprotetores observados após o 
processo isquêmico. Por último, é importante destacar que, se por um lado os HT apresentam esses importantes efeitos benéficos para o miocárdio, por outro o excesso de HT é muitas vezes acompanhado de efeitos adversos, como taquicardia sinusal ou arritmias, o que certamente pode limitar a sua aplicação na prática clínica (Pantos et al., 2004).

Após ter confirmado o efeito cardioprotetor do HT no modelo utilizado neste estudo, o passo seguinte foi identificar o possível papel do Sistema Renina Angiotensina (SRA) nesta ação cardioprotetora exercida pelo hormônio. Este questionamento se coloca uma vez que trabalhos prévios de nosso grupo já apresentaram à comunidade científica dados expressivos sobre a participação do SRA como um dos mediadores das ações cardiovasculares dos Hormônios Tiroideanos. Neste sentido, alguns estudos já demonstraram que a administração de inibidores da enzima conversora de Ang I (ECA) ou dos receptores AT1 e AT2 foram capazes de prevenir a hipertrofia cardíaca induzida pelos HT (Hu et al, 2003; Diniz et al., 2009; Carneiro-Ramos et al., 2010; Barreto-Chaves et al., 2010). Esta interação ocorre localmente, no próprio tecido cardíaco, uma vez que já foi demonstrado, tanto "in vivo" como "in vitro", que o T3 estimula a expressão gênica de renina, além de aumentar a síntese e secreção de angiotensinogênio, e alterar a expressão dos receptores de Ang II neste tecido, de maneira independente do SRA sistêmico (Dzau, 1986; Kobori et al., 1997).

Sabendo da relação íntima entre estes dois sistemas endócrinos, e levando em consideração que o SRA é regulado durante a isquemia miocárdica e injúria de I/R, decidimos avaliar o papel deste sistema neste modelo, uma vez que os mecanismos de ação de seus componentes ainda não foram amplamente estudados na I/R (Dudley et al., 1990; Horiuchi et al., 1999). Neste sentido, durante a isquemia ocorre modulação do SRA com aumento da expressão de algumas proteínas envolvidas no sistema, sendo uma estratégia de cardioproteção a diminuição de Ang II e, consequentemente, a estimulação de seus receptores. A eficácia deste procedimento, no entanto, é debatida (Przyklenk et al., 1993), uma vez que outra estratégia de cardioproteção que vem sendo utilizada clinicamente consiste na diminuição da ação dos 
receptores AT1 e AT2 através da utilização de antagonistas ou inibidores farmacológicos.

Alguns trabalhos já demonstraram que o receptor AT2 pode funcionar como um importante mediador de cardioproteção. Nesses estudos os autores observaram, em corações isolados de ratos, que a diminuição da expressão do receptor AT2 promove prejuízo funcional no processo de I/R. Com o bloqueio seletivo deste receptor, realizado agudamente através da perfusão coronariana com PD123319, 5 min antes do processo isquêmico, ocorre aumento da expressão protéica de AT2, ocasionando melhora na recuperação da função cardíaca (Przyklenk et al., 1993; Yi Xu et al., 2002). No presente estudo nós mostramos que a inibição farmacológica do receptor AT2 por 14 dias também foi capaz de melhorar a recuperação cardíaca após a injúria de $\mathrm{I} / \mathrm{R}$, através do aumento significativo da contratilidade $(+\mathrm{dP} / \mathrm{dt})$ e da velocidade de relaxamento $(-\mathrm{dP} / \mathrm{dT})$, após 45 minutos de reperfusão. Embora nenhuma diferença tenha sido encontrada no parâmetro de LVDP durante a reperfusão, é interessante notar que este parâmetro era significativamente menor em relação ao grupo controle no período de estabilização do grupo PD, diferença esta que foi abolida no período de reperfusão.

Embora trabalhos envolvendo o tratamento crônico do repeptor AT2 sejam escassos, diversos estudos com outros modelos de inibição deste receptor já demonstraram grande participação do mesmo na função cardíaca. Em camundongos geneticamente modificados, que não expressam o receptor AT2, foi observado, além de uma redução da sobrevivência, o desenvolvimento de uma dilatação do ventrículo esquerdo após infarto do miocárdio, induzido através da oclusão da artéria coronária descendente anterior esquerda. $O$ estudo conclui que os mecanismos relacionados ao papel cardioprotetor do receptor AT2 ainda não foram elucidados, embora exista uma possível relação entre o aumento da expressão deste receptor e a proteção do coração após o processo isquêmico (Oishi et al., 2002).

Por outro lado, em trabalho recente de programação fetal, os autores encontraram resultados instigantes com relação ao receptor AT2, demonstrando que situações de hipóxia fetal promovem aumento da expressão do receptor AT2, através da regulação negativa dos receptores de 
glicocorticóides. Na fase adulta, esses animais apresentaram vulnerabilidade à injúria de isquemia quando submetidos à $\mathrm{l} / \mathrm{R}$. Entretanto, quando o pré tratamento com PD foi realizado agudamente durante a perfusão dos corações, houve melhora da função cardíaca (Xue et al., 2011). Com base nesse estudo, os resultados indicam que o bloqueio farmacológico deste receptor está envolvido com cardioproteção, no entanto, este fenômeno parece estar diretamente associado e dependente da concentração de inibidor PD utilizada, além de ser influenciada por uma possível participação do receptor AT1 (Ford et al., 2000).

Embora alguns estudos tenham se detido a avaliar o papel dos receptores de Ang II no modelo de I/R, essa resposta ainda não é clara, uma vez que a cada dia novas informações sobre o SRA são desvendadas, o que torna este sistema cada vez mais complexo e difícil de ser entendido em sua plenitude. Neste sentido, é interessante que os efeitos dos bloqueadores dos receptores AT1 e AT2 durante a l/R podem inclusive envolver a sua interação ou "conversas cruzadas" no nível da transcrição gênica. Embora esta relação ainda não tenha sido demonstrada em cultura de células, o bloqueio do receptor AT1 durante a I/R promove aumento seletivo nos níveis de RNAm para AT1 e diminuição dos de AT2, resultando na piora da recuperação da função cardíaca. No entanto, de maneira diferente, foi visto no mesmo estudo uma recuperação da função cardíaca pós-isquêmica quando o receptor AT2 foi bloqueado farmacologicamente, havendo aumento da expressão protéica deste receptor, e inibição do aumento do RNAm do receptor AT1 e de seus possíveis efeitos deletérios na função cardíaca. (Yin Xu et al., 2002).

Embora nós tenhamos observado uma melhora da função cardíaca após inibição farmacológica do receptor AT2, diferentemente de alguns dos estudos anteriores, a expressão protéica do receptor AT2 não aumentou no grupo tratado com o PD. Entretanto, o modelo utilizado neste estudo foi de uma inibição farmacológica crônica do receptor AT2 por 14 dias, e não de modo agudo, através da perfusão das coronárias no coração isolado, como a utilizada pelos autores (Przyklenk et al., 1993; Yi Xu et al., 2002). Embora essa inibição não tenha ocasionado alteração na expressão protéica do receptor 
AT1, também não podemos descartar a possível interação destes recetores a níveis gênicos.

Sabendo que a Ang II age através desses dois receptores de membrana específicos, o AT1 e o AT2, a mensuração dos níveis de Ang II, o principal peptídeo efetor do SRA, é de fundamental importância, uma vez que este peptídeo ultiliza-se de seus receptores para desencadear suas ações. $O$ método mais fidedigno para mensurar os níveis deste peptídeo no plasma ou no tecido é a Cromatrografia Líquida de Alto Desempenho (HPLC), técnica que ainda está sendo estabelecida em nosso laboratório. Ainda assim, na tentativa de ter uma idéia de como estes níveis se encontravam no tecido cardíaco, realizamos a técnica de western blotting, utilizando anticorpo que reconhece os peptídeos Angl/Angll. Os resultados deste método são questionáveis, uma vez que não é um ensaio específico e preciso para a determinação dos níveis de Ang II, no entanto era o que tínhamos no momento à nossa disposição. Esperamos poder confirmá-los após a realização das determinações por HPLC, as quais serão realizadas assim que possível.

Ainda com relação aos níveis de Angl/ll foi notado um aumento desses peptídeos nos grupos T3 e PD+T3, ainda que significativo apenas no grupo $\mathrm{PD}+\mathrm{T3}$. Este aumento nesses dois grupos experimentais era esperado, uma vez que, como já descrito previamente, em situação de hipertiroidismo o SRA encontra-se, de modo geral, ativado. Neste caso, além de não termos observado alteração neste parâmetro no grupo PD, em relação ao controle, a administração desse inibidor concomitantemente ao tratamento com o T3 não foi capaz de alterar os efeitos do hormônio no aumento dos níveis de Ang II.

Um outro resultado que merece ser discutido neste estudo é aquele referente à participação do receptores de Ang II no processo de hipertrofia cardíaca induzido pelos elevados níveis de hormônios tiroideanos. Neste sentido, com base em nossos resultados, nós observamos que o bloqueio do receptor AT2, embora tenha abolido o efeito cardioprotetor mediado pelo HT, não foi capaz de prevenir o efeito hipertrófico promovido pelo mesmo, uma vez levou à redução da massa cardíaca da ordem de apenas 10\%. Estudos anteriores de nosso laboratório podem, aparentemente, parecer contraditórios, uma vez que Carneiro-Ramos e cols. (2010) já haviam demonstrado uma 
prevenção da ordem de $40 \%$ no ganho de massa muscular cardíaco induzido pelo hipertiroidismo. No entanto, é importate ressaltar que, naquele estudo, o modelo de indução ao hipertiroidismo havia sido promovido após administração de T4 e não T3, o qual é considerado o hormônio biologicamente ativo deste sistema endócrino (Yen, 2001). Assim é possível que essa seja a explicação para a diferente eficiência do receptor AT2 em bloquear mais intensamente ou não o efeito hipertrófico do HT. Ainda, neste estudo nós observamos que a indução ao hipertiroidismo foi capaz de modular a expressão protéica do receptor AT2, que se apresentou $36 \%$ maior no grupo T3, em relação ao grupo controle. Essa diferença não foi mais obervada quando o receptor AT2 foi bloqueado conjuntamente, o que pode ter contribuído significativamente para a piora da função cardíaca observada neste grupo.

Ainda com relação à participação dos receptores de Ang II nos efeitos hipertróficos promovidos pelos $\mathrm{HT}$, trabalho realizado pelo grupo do Prof. Pantos demonstrou que o tratamento combinado com o inibidor farmacológico do receptor AT1 foi capaz de reduzir significativamente a hipertrofia cardíaca induzida pelos HT, entretanto, a melhora da recuperação cardíaca pósisquemia, clássica do tratamento com HT, não foi abolida com a inibição deste receptor, permanecendo o efeito cardioprotetor do HT na recuperação da função cardíaca no modelo de I/R (Pantos et al., 2005). Estes dados põem então em xeque a participação do receptor AT1 na cardioproteção mediada pelo $\mathrm{HT}$, não excluindo, no entanto, a participação dos demais componentes do SRA neste processo.

O T3 exerce profundos efeitos no crescimento celular, diferenciação, termogênese, além do aumento do metabolismo em geral e função contrátil do cardiomiócito (Heather et al. 2010; Li e Keaney, 2010). Estas ações evidenciam a atuação deste hormônio em processos que levam ao consumo de considerável quantidade de ATP, podendo resultar na ativação de uma das enzimas que controla esse gasto energético, a quinase ativada por AMP, também denominada AMPK. A ativação da AMPK é provocada por diversos fatores como hormônios e citocinas que são secretados em resposta às influências externas. Estudos recentes já demostraram que a AMPK parece desempenhar uma função modulatória em diversas patologias 
cardiovasculares, como hipertensão, hipertrofia ventricular, processos isquêmicos e outras patologias que deflagram ativação de mecanismos relacionados à injúria do tecido cardíaco e de vasos de modo geral ( $\mathrm{Li}$ e Keaney, 2010). A AMPK é uma quinase que atua modulando uma série de enzimas, permitindo que a tradução protéica diminua ou até cesse, até que os níveis de ATP sejam restaurados, uma vez que o processo de síntese protéica exige alto gasto energético e o ATP deve ser poupado para outras regulações mais urgentes; é nesse sentido que a AMPK exerce um papel essencial na regulação deste metabolismo (Kemp et al., 2003).

Recentemente, um grupo de pesquisa comparou os efeitos de dois estímulos, a Ang II e os HT, na fosforilação dos distintos sítios da AMPK, tanto in vivo como in vitro. Os resultados mostraram que o tratamento com $\mathrm{HT}$ foi capaz de aumentar os níveis da AMPK fosforilada na Tre $^{172}$, corroborando com os dados que encontramos no presente estudo, sem que a Ang II promovesse qualquer efeito sobre os níveis da AMPK fosforilada (Jiang et al., 2010). Os nossos resultados mostraram que o tratamento com T3 ativa a AMPK, e podemos hipotetizar que este estado de ativação parece ser necessário para a melhora da função cardíaca após injúria de $\mathrm{l} / \mathrm{R}$, uma vez que os corações tratados com T3 e PD conjuntamente apresentaram redução da fosforilação da AMPK no sítio da $\operatorname{Ter}^{172}$, além de impedir o aumento dos níveis de AT2, que encontravam-se com expressão aumentada no grupo T3. Todas essas alterações parecem ter influenciado na piora da função cardíaca observada neste grupo, em relação ao grupo T3, que mostrou proteção do miocárdio através da melhora da função cardíaca e modulação de determinadas proteínas envolvidas com cardioproteção.

Por fim, é importante ressaltar ainda que mesmo os tratamentos utilizados neste estudo tendo promovido alterações expressivas na função cardíaca pós-isquemia e na modulação de proteínas envolvidas com cardioproteção, os corações, quando in vivo não apresentavam sinais de insuficiência, e essa constatação foi mais uma vez confirmada pelo nosso grupo com base na ausência de congestão pulmonar e hepática observada nos animais dos diferentes grupos experimentais. 
Nossos resultados sugerem que parte da cardioproteção induzida pelo HT é mediada pelo receptor AT2, o qual também está envolvido com a proteção do miocárdio após $\mathrm{I} / \mathrm{R}$. Os mecanismos pelos quais o receptor AT2 exerce cardioproteção foram pouco estudados e a sua relação com o HT neste processo era desconhecida. De acordo com as ações clássicas deste receptor e do HT, e das vias intracelulares deflagradas pelos mesmos, podemos sugerir que vias intracelulares relacionadas à produção de óxido nítrico (Li et al., 2004) e outras espécies reativas de oxigênio (Evora et al., 1997), bem como proteínas reguladoras do metabolismo, como a AMPK (Morrisson, 2011), e vias envolvidas com a hipertrofia cardíaca e combate ao estresse, como as MAPKs (Saurin et al., 2000; Li et al., 2005) e PI3K/Akt (Diniz et al., 2009), podem ser coadjuvantes nesta ação em proteger o tecido cardíaco da injúria de I/R. 


\section{CONCLUSÕES}

Com base nos resultados apresentados, podemos concluir que:

- O Hormônio Tiroideano (T3) exerceu efeito cardioprotetor e promoveu aumento da expressão do receptor AT2 e dos níveis de AMPK fosforilada;

- A inibição do receptor AT2 com PD 123,319 exerceu efeito cardioprotetor quando administrado sozinho;

- O receptor AT2 está envolvido com a cardioproteção mediada pelo T3, uma vez que a inibição farmacológica deste receptor foi capaz de abolir o efeito cardioprotetor do HT, além de inibir a modulação do receptor AT2 e da fosforilação da AMPK. 


\section{REFERÊNCIAS ${ }^{1}$}

Anjos-Ramos L, Carneiro-Ramos MS, Diniz GP, Martins-Silva J, Barreto-Chaves ML. Early cardiac hypertrophy induced by thyroxine is accompanied by an increase in VEGF-A expression but not by an increase in capillary density. Virchows Arch. 2006;448:472-479.

Bak MI, Ingwall JS. Contribution of $\mathrm{Na}(+) / \mathrm{H}(+)$ exchange to $\mathrm{Na}(+)$ overload in the ischaemic hypertrophied hyperthyroid rat heart. Cardiovasc Res. 2003;57(4):10041014.

Barreto-Chaves ML, Carrillo-Sepúlveda MA, Carneiro-Ramos MS, Gomes DA, Diniz GP. The crosstalk between thyroid hormones and the Renin-Angiotensin System. Vascul Pharmacol. 2010;52(3-4):166-70.

Bedecs, K. et al. Angiotensin II type 2 receptors mediate inhibition of mitogenactivated protein kinase cascade and functional activation of SHP-1 tyrosine phosphatase. Biochem J. 1997;325:449-54.

Buser PT, Wikman-Coffelt J, Wu ST, Derugin N, Parmley WW, Higgins CB. Postischaemic recovery of mechanical performance and energy metabolism in the presence of left ventricular hypertrophy. A 31P-MRS study. Circ Res. 1990;66 (3): 735746.

Canaris GJ, Manowitz NR, Mayor G, Ridgway EC. The Colorado thyroid disease prevalence study. Arch Intern Med. 2000;160:526-534.

Carneiro-Ramos MS, Diniz GP, Almeida J, Vieira RL, Pinheiro SV, Santos RA, BarretoChaves ML. Cardiac angiotensin II type I and type II receptors are increased in rats submitted to experimental hypothyroidism. J Physiol. 2007;15(583(Pt 1)):213-23.

Carneiro-Ramos MS, Diniz GP, Nadu AP, Almeida J, Vieira RLP, Santos RAS, BarretoChaves MLM. Blockage of Angiotensin II type 2 receptor prevents thyroxine-mediated cardiac hypertrophy by blocking Akt activation. Basic Research in Cardiology. 2010;105(3):325-35.

Carneiro-Ramos MS, Silva VB, Santos RA, Barreto-Chaves ML. Tissue-specific modulation of angiotensin-converting enzyme (ACE) in hyperthyroidism. Peptides. 2006;27:2942-2949.

Cokkinos, D.V.P.; Pantos, C.; Heusch, G.; Taegtmeyer, H. Myocardial ischemia: from mechanisms to therapeutic potentials. New York: Springer Science+Business Media. 2006; 201p.

Danzi S, Klein I.Thyroid hormone and the cardiovascular system. Minerva Endocrinol. 2004;29(3):139-50.

Diniz, G. P. et al. Angiotensin type 1 (AT1) and type 2 (AT2) receptors mediate the increase in TGF-beta1 in thyroid hormone-induced cardiac hypertrophy. Pflugers Arch. 2007;454(1):75-81.

\footnotetext{
${ }^{1}$ De acordo com:

International Committee of Medical Journal Editors. Uniform requerements for manuscripts submitted to Biomedical Journal: sample references. Aviable from: http://www.icmje.org [2007 May 22]
} 
Diniz, G.P.; Carneiro-Ramos, M.S.; Barreto-Chaves, M.L. Angiotensin type 1 receptor mediates thyroid hormone-induced cardiomyocyte hypertrophy through the Akt/GSK-3beta/mTOR signaling pathway. Basic Res Cardiol. 2009;104(6): 653-67.

Dorn, G.W. Novel pharmacotherapies to abrogate postinfarction ventricular remodeling. Nat Rev Cardiol. 2009;6(4):283-91.

Dostal DE, Baker K. The cardiac renin-angiotensin system. Conceptual or regulator of cardiac function? Circ Res. 1999;85:643-50.

Dudley DT, Panek RL, Major TC, Lu GH, Bruns RF, Klinkefus BA, Hodges JC, and Weishaar RE. Subclasses of angiotensin II binding sites and their functional significance. Mol Pharmacol. 1990;38:370-37.

Dyck JR, Lopaschuk GD. AMPK alterations in cardiac physiology and pathology: Enemy or Ally? J Physiol. 2006;574:95-112.

Dyke CM, Ding M, Abd-Elfattah AS, Loesser K, Dignan RJ, Wechsler AS, Salter DR. Effects of triiodothyronine supplementation after myocardial ischaemia. Ann Thorac Surg. 1993;56 (2):215-222.

Dyke CM, Yeh T Jr, Lehman JD, Abd-Elfattah A, Ding M, Wechsler AS, Salter DR. Triiodothyronine-enhanced left ventricular function after ischaemic injury. Ann Thorac Surg. 1991;52 (1): 14-19.

Dzau, V.J. Significance of the vascular renin-angiotensin pathway. Hypertension. 1986;8(7):553-9.

Erkan E, Sakarcan A, Haklar G, Yalcin S. Thyroxine prevents reoxugenation injury in isolated proximal tubule cells. Pediatr Nephrol. 2003;18 (7): 636-643.

Evoara PRB, Pearson PJ, Seccombe JF, Schaff HV. Lesão de Isquemia-Reperfusão. Aspectos Fisiopatológicos e a Importância da Função Endotelial. Arq Bras Cardiol, 1996;66(4):239-245.

Fallen EL, Elliott WC, Gorlin R. Apparatus for study of ventricular function and metabolism in the isolated perfused rat heart. J Appl Physiol. 1967;22(4):836-9.

Ford WR, Clanachan AS, Jugdutt BI. Characterization of cardioprotection mediated by AT2 receptor antagonism after ischemia-reperfusion in isolated working rat hearts. $J$ Cardiovasc Pharmacol Ther. 2000;5(3):211-21.

Hausenloy DJ, Yellon DM. Survival kinases in ischemic preconditioning and postconditioning. Cardiovasc Res. 2006;70:240-253.

Heather LC, Cole MA, Atherton HJ, Coumans WA, Evans RD, Tyler DJ, Glatz JFC, Luiken JJFP, Clarke K. Adenosine monophosphate-activated protein kinase activation, substrate transporter translocation, and metabolism in the contracting hyperthyroid rat heart. Endocrinology. 2010;24(1):422-431.

Holland FW 2nd, Brown PS Jr, Clark RE. Acute severe postischaemic myocardial depression reversed by triiodothyronine. Ann Thorac Surg. 1992;54 (2): 301-305. 
Horiuchi, M. et al. Recent progress in angiotensin II type 2 receptor research in the cardiovascular system. Hypertension. 1999;33(2):613-21.

Hu LW, Liberti EA, Barreto-Chaves ML. Myocardial ultrastructure in cardiac hypertrophy induced by thyroid hormone--an acute study in rats. Virchows Arch. 2005;446:265-269.

Hu, L. W. et al. Thyroxine-induced cardiac hypertrophy: influence of adrenergic nervous system versus renin-angiotensin system on myocyte remodeling. Am J Physiol Regul Integr Comp Physiol. 2003;285(6):1473-80.

Huang, X. C. et al. Mitogen-activated protein kinases in rat brain neuronal cultures are activated by angiotensin II type 1 receptors and inhibited by angiotensin II type 2 receptors. J Biol Chem. 1996;271(26):15635-41.

Ichihara S, Senbonmatsu T, Price E, Jr., Ichiki T, Gaffney FA, Inagami T. Angiotensin II type 2 receptor is essential for left ventricular hypertrophy and cardiac fibrosis in chronic angiotensin II-induced hypertension. Circulation. 2001;(104):346-351.

Jiang SY, Xu M, Ma XW, Xiao H, Zhang YY. Distinct AMPK phosphorylation site characterizes cardiac hypertrophy induced by L-thyroxine and angiotensin II. Clin Exp Pharmacol Physiol. 2010,37(9):919-25.

Kadletz M, Mullen PG, Ding M, Wolfe LG, Wechsler AS. Effect of triiodothyronine on postischaemic myocardial function in the isolated heart. Ann Thorac Surg. 1994;57 (3): 657-662.

Kahaly, GJ, Dillmann WH. Tyroid hormone action in the heart. Endocr Rev. 2005;26(5):704-28.

Kemp BE, Stapleton D, Campbell DJ, Chen ZP, Murthy S, Walter M, Gupta A, Adams JJ, Katsis F, van Denderen B, Jennings IG, Iseli T, Michell BJ, Witters LA. AMPactivated protein kinase, super metabolic regulator. Biochem Soc Trans, 31(Pt 1):162168, 2003.

Kilbourn MR, Ma B, Butch ER, Quesada C, Sherman PS. Anesthesia increases in vivo $\mathrm{N}-([(18) F]$ fluoroethyl)piperidinyl benzilate binding to the muscarinic cholinergic receptor. Nucl Med Biol. 2007;34(5):479-82.

Kim S, Iwao H. Molecular and cellular mechanisms of angiotensin II-mediated cardiovascular and renal diseases. Pharmacol Rev. 2000;52(1):11-34

Klemperer JD, Klein I, Gomez M, Helm RE, Ojamaa K, Thomas SJ, Isom OW, Krieger $\mathrm{K}$. Thyroid hormone treatment after coronary-artery bypass surgery. $\mathrm{N}$ Engl $\mathrm{J}$ Med. 1995;333 (23):1522- 1527.

Klemperer JD. Thyroid hormone and cardiac surgery. Thyroid. 2002;12 (6):517-521.

Kobori H, Ichihara A, Suzuki H, Miyashita Y, Hayashi M, Saruta T. Thyroid hormone stimulates renin synthesis in rats without involving the sympathetic nervous system. Am J Physiol. 1997;(272):227-232. 
Kolocassides KG, Galinanes M, Hearse DJ. Dichotomy of ischaemic pre-conditioning. Improved postischaemic contractile function despite intensification of ischaemic contracture. Circulation. 1996;93:1725-1733.

Leon H, Atkinson LL, Sawicka J, Strynadka K, Lopaschuk GD, Schulz R. Pyruvate prevents cardiac dysfunction and AMP-activated protein kinase activation by hydrogen peroxide in isolated rat hearts. Can J Physiol Pharmacol. 2004;82:409-416.

Li C e Keaney JF. AMP-activated protein kinase: a stress-responsive kinase with implications for cardiovascular disease. Curr Opin Pharmacol. 2010;10(2):111-115.

Li J, Miller EJ, Ninomiya-Tsuji J, Russell 3rd RR, Young LH. AMP-activated protein kinase activates p38 mitogen-activated protein kinase by increasing recruitment of p38 MAPK to TAB1 in the ischemic heart. Circ Res. 2005;97:872-9.

Li J,Hu X, Selvakumar P, Russell 3rd RR, Cushman SW, Holman GD, et al. Role of the nitric oxide pathway in AMPK-mediated glucose uptake and GLUT4 translocation in heart muscle. Am J Physiol Endocrinol Metab. 2004;287:E834-41.

Liu Q, Clanachan AS, Lopaschuk GD. Acute effects of triiodothyronine on glucose and fatty acid metabolism during reperfusion of ischaemic rat hearts. Am J Physiol. 1998;275(3):E392-399.

Luptak I, Shen M, He H, Hirshman MF, Musi N, Goodyear LJ, et al. Aberrant activation of AMP-activated protein kinase remodels metabolic network in favor of cardiac glycogen storage. J Clin Invest. 2007;117:1432-9.

Ma H, WangJ, Thomas DP, Tong C, Leng L,WangW, et al. Impaired macrophage migration inhibitory factor-AMP-activated protein kinase activation and is- chemic recovery in the senescent heart. Circulation. 2010;122:282-92.

Maizels ET, Peters CA, Kline M, Cutler RE Jr, Shanmugam M, Hunzicker-Dunn M. Heat-shock protein-25/27 phosphorylation by the delta isoform of protein kinase $\mathrm{C}$. Biochem J. 1998;332 (Pt 3):703-12.

Matsubara H, Kanasaki M, Murasawa M, Tsukaguchi Y, Nio Y, and Inada M. Differential gene expression and regulation of angiotensin II receptor subtypes in rat cardiac fibroblasts and cardiomyocytes in culture. J Clin Invest. 1994;93: 1592-1601.

Mehta, P.K.; Griendling, K.K. Angiotensin II cell signaling: physiological and pathological effects in the cardiovascular system. Am $J$ Physiol Cell Physiol 2007; 292(1):82-97.

Miller EJ, Li J, Leng L, McDonald C, Atsumi T, Bucala R, et al. Macrophage migration inhibitory factor stimulates AMP-activated protein kinase in the ischaemic heart. Nature. 2008;451:578-82.

Morrison A, Li J. PPAR- $\gamma$ and AMPK - Advantageous targets for myocardial ischemia/reperfusion therapy. Biochem Pharmacol. 2011;82(3):195-200.

Novitzky D, Cooper DK, Swanepoel A. Inotropic effect of triiodothyronine (T3) in low cardiac output following cardioplegic arrest and cardiopulmonary bypass: an initial experience in patients undergoing open heart surgery. Eur $\mathrm{J}$ Cardiothorac Sur. 1989;3(2):140-145. 
Novitzky D, Matthews N, Shawley D, Cooper DK, Zuhdi N. Triiodothyronine in the recovery of stunned myocardium in dogs. Ann Thorac Surg. 1991;51(1):10-16.

Nunes, M.T. Homônios Tiroideanos: Mecanismo de Ação e Importância Biológica. Arq Bras Endocrinol Metab 2004,47(6):193-262.

Oishi Y, Ozono R, Yano Y, Teranishi Y, Akishita M, Horiuchi M, Oshima T, Kambe M. Cardioprotective role of AT2 receptor in postinfarction left ventricular remodeling. Hypertension. 2003; 41(3 Pt 2):814-8.

Ojamaa K, Kenessey A, Shenoy R, Kleinl (2000) Thyroid hormone metabolism and cardiac gene expression after acute myocardial infarction in the rat. Am J Physiol. 2000;279:E1319-E1324.

Pantos C, Cokkinos DD, Tzeis S, Malliopoulou V, Mourouzis I, Carageorgiou H, Limas C, Varonos D, Cokkinos DV. Hyperthyroidism is associated with preserved preconditioning capacity but intensified and accelerated ischaemic contracture in rat heart. Basic Res Cardiol. 1999;94: 254-260.

Pantos C, Malliopoulou V, Mourouzis I, Karamanoli E, Paizis I, Steinberg N, Varonos D, Cokkinos DV. Long-term thyroxin administration protects the heart in a pattern similar to ischemic preconditioning. Thyroid. 2002;12(4):325-9.

Pantos C, Malliopoulou V, Mourouzis I, Karamanoli E, Tzeis SM, Carageorgiou H, Varonos D, Cokkinos DV. Long-term thyroxine administration increases HSP70 mRNA expression and attenuates p38 MAP kinase activity in response to ischaemia. $J$ Endocrinol. 2001;170: 207-215.

Pantos C, Malliopoulou V, Mourouzis I, Sfakianoudis K, Tzeis S, Doumba P, Xinaris Ch, Cokkinos AD, Carageorgiou H, Varonos D, Cokkinos DV. Propylthiouracil induced hypothyroidism is associated with increased tolerance of the isolated rat heart to ischaemia-reperfusion. J Endocrinol. 2003;178 (3): 427-435.

Pantos C, Malliopoulou V, Mourouzis I,Karamanoli E, Paizis I, Steimberg N,Varonos D, Cokkinos DV. Long-term thyroxine administration protects the heart in a similar pattern as ischaemic preconditioning. Thyroid. 2002;12: 325-329.

Pantos C, Malliopoulou V, Varonos DD, Cokkinos DV. Thyroid hormone and phenotypes of cardioprotection. Basic Res Cardiol. 2004;99(2):101-20.

Pantos C, Mourouzis I, Tzeis S, Malliopoulou V, Cokkinos DD, Asimakopoulos P, Carageorgiou H, Varonos DD, Cokkinos DV. Propranolol diminishes cardiac hypertrophy but does not abolish acceleration of the ischaemic contracture in hyperthyroid hearts. J Cardiovasc Pharmacol. 2000;36:384-389.

Pantos C, Mourouzis I, Tzeis S, Moraitis P, Malliopoulou V, Cokkinos DD, Carageorgiou $\mathrm{H}$, Varonos D, Cokkinos DV. Dobutamine administration exacerbates postischaemic myocardial dysfunction in isolated rat hearts; An effect reversed by thyroxine pre-treatment. Eur J Pharmacol. 2003;460: 155-161.

Pantos C, Paizis I, Mourouzis I, Moraitis P, Tzeis S, Karamanoli E, Mourouzis C, Karageorgiou H, Cokkinos DV. Blockade of angiotensin II type 1 receptor diminishes 
cardiac hypertrophy, but does not abolish thyroxin-induced preconditioning. Horm Metab Res. 2005;37(8):500-4.

Pantos C, Vassiliki V, Dennis D C, Dennis V. Thyroid hormone and phenotypes of cardioprotection. Basic Res Cardiol. 2004;99: 101-20.

Pantos CI, Malliopoulou VA, Mourouzis IS, Karamanoli EP, Tzeis SM, Carageorgiou HC, Varonos DD, Cokkinos DV. Long-term thyroxine administration increases heat stress protein-70 mRNA expression and attenuates p38 MAP kinase activity in response to ischaemia.J Endocrinol. 2001;170(1):207-15.

Przyklenk K, Kloner RA "Cardioprotection" by ACE-inhibitors in acute myocardial ischemia and infarction? Basic Res Cardiol. 1993;88 Suppl 1:139-54

Re, R.N. Mechanisms of disease: local renin-angiotensin-aldosterone systems and the pathogenesis and treatment of cardiovascular disease. Nat Clin Pract Cardiovasc Med. 2004;1(1):42-7.

Russell RR, Li J, Coven DL, Pypaert M, Zechner C, Palmeri M, et al. AMP- activated protein kinase mediates ischemic glucose uptake and prevents postischemic cardiac dysfunction, apoptosis, and injury. J Clin Invest. 2004;114:495-503.

Santos, RA. Ferreira AJ, Simões E Silva AC.. Recent advances in the angiotensinconverting enzyme 2-angiotensin(1-7)- Mas axis. Exp Physiol. 2008;93(5):519-27.

Saurin AT, Martin JL, Heads RJ, Foley C, Mockridge JW, Wright MJ, Wang Y, Marber MS. The role of differential activation of p38-mitogen-activated protein kinase in preconditioned ventricular myocytes. FASEB J. 2000;14(14):2237-46.

Sernia C, Marchant C, Brown L, Hoey A. Cardiac angiotensin receptors in experimental hyperthyroidism in dogs. Cardiovascular research. 1993;27:423-428.

Skrzypiec-Spring M, Grotthus B, Szelag A, Schulz R. Isolated heart perfusion according to Langendorff---still viable in the new millennium. Journal of pharmacological and toxicological methods. 2007,55:113-126.

Thornburg KL. Foetal programming reveals the dark side of AT(2)R. Cardiovasc Res. $2011 ; 89(2): 260-1$.

Van Der Vusse GJ, Coumans WA, Ulrich M, Van Bilsen M. Thyroxine induced alteration in cardiac energy metabolism. J Mol Cell Cardiol. 1998;30:A110.

Venditti P, Masullo P, Agnisola C, Di Meo S. Effect of vitamin E on the response to ischaemia-reperfusion of Langendorff heart preparations from hyperthyroid rats. Life Sci. 2000;66(8):697-708.

Volpe, M. et al. Angiotensin II AT2 receptor subtype: an uprising frontier in cardiovascular disease? J. Hypertens. 2003;21(8) 1429-43.

Warner FJ, Smith AI, Hooper NM, Turner AJ. Angiotensin-converting enzyme-2: a molecular and cellular perspective. Cell Mol Life Sci. 2004;61(21):2704-13. 
Xu Y, Kumar D, Dyck JR, Ford WR, Clanachan AS, Lopaschuk GD, Jugdutt BI. AT(1) and $\mathrm{AT}(2)$ receptor expression and blockade after acute ischemia-reperfusion in isolated working rat hearts Am J Physiol Heart Circ Physiol. 2002; 282(4):H1206-15

Xue Q, Dasgupta C, Chen M, Zhang L. Foetal hypoxia increases cardiac AT(2)R expression and subsequent vulnerability to adult ischaemic injury.Cardiovasc Res. $2011 ; 89(2): 300-8$.

Yang BC, Phillips MI, Ambeuhl PEJ, Shen LP, Mehta P, Mehta JL. Increase in angiotensin II type 1 receptor expression immediately after ischemia-reperfusion in isolated rat hearts. Circulation. 1997;96: 922-926.

Yang BC, Phillips MI, Zhang YC, Kimura B, Shen LP, Mehta P, Mehta JL. Critical role of AT1 receptor expression after ischemia/reperfusion in isolated rat hearts: beneficial effect of antisense oligodeoxynucleotides directed at AT1 receptor mRNA. Circ Res. 1998;83:552-559.

Yen, P M. Physiological and Molecular Basis of Thyroid Hormone Action. Physiol Rev. 2001;81(3):1097-1142.

Yi Xu, Dinender Kumar, Jason R. B. Dyck, William R. Ford, Alexander S. Clanachan, Gary D. Lopaschuk and Bodh I. Jugdutt. Am J Physiol Heart Circ Physiol. 2002;82:1206-1215.

Yoshiyama M, Kim S, Yamagishi H, Omura T, Tani T, Yanagi S, Toda I, Teragaki M, Akioka K, Takeuchi K, and Takeda T. Cardioprotective effect of the angiotensin II type 1 receptor antagonist TCV-116 on ischemia-reperfusion injury. Am Heart J. 1994;128: $1-6$.

Young LH. AMPK conducts the ischemic stress response orchestra. Circulation. 2008;117:832-840.

Zhu, Y.C. et al. Role of angiotensin AT1 and AT2 receptors in cardiac hypertrophy and cardiac remodelling. Clin Exp Pharmacol Physiol. 2003;30(12):911-8. 